\title{
Seasonal variation of atmospheric bulk deposition along an urbanization gradient in Nuevo Leon, Mexico
}

\author{
Darithsa LOYA-GONZÁLEZ ${ }^{1}$, Israel CANTÚ-SILVA ${ }^{1 *}$, Humberto GONZÁLEZ-RODRÍGUEZ ${ }^{1}$, \\ Daniel LÓPEZ-SERNA ${ }^{2}$ and J.M. ALFARO-BARBOSA ${ }^{2}$
}

\author{
${ }^{1}$ Universidad Autónoma de Nuevo León, Facultad de Ciencias Forestales, Carretera Nacional No. 85, Km 145, Linares, \\ Nuevo León, 67700, México. \\ ${ }^{2}$ Universidad Autónoma de Nuevo León, Facultad de Ciencias Químicas, Av. Universidad S/N, Ciudad Universitaria, \\ San Nicolás de los Garza, Nuevo León, 66451, México. \\ *Corresponding author: icantu59@gmail.com
}

Received: July 9, 2020; accepted: January 13, 2021

\begin{abstract}
RESUMEN
Se estudió la deposición atmosférica a granel en un gradiente de urbanización en el estado de Nuevo León, México. Se monitorearon siete sitios dentro del Área Metropolitana de Monterrey (AMM) y dos sitios rurales (Allende y Linares) durante un año, con el propósito de identificar posibles patrones entre sitios. Un total de 32 eventos de lluvia fueron considerados. Se encontró un $\mathrm{pH}$ promedio de $7.15 \pm 0.02$, indicando la presencia de sustancias neutralizantes en la lluvia, así como una Conductividad Eléctrica promedio de $153.96 \pm 6.83 \mu \mathrm{S} /$ $\mathrm{cm}$. La deposición acumulada anual sigue el orden decreciente $\mathrm{Ca}>\mathrm{K}>\mathrm{Mg}>\mathrm{Fe}>\mathrm{Zn}>\mathrm{Mn}>\mathrm{Cu}>\mathrm{Cd}>\mathrm{Ni}$ y no muestra diferencias significativas entre zonas urbanas y rurales, excepto para $\mathrm{Ca}(\mathrm{p}=0.017)$. El Análisis de Componentes Principales identificó que los metales (Cu, Zn, Ni, Mn y Cd) caracterizan el depósito atmosférico dentro del AMM, comportamiento que se mantiene en todo el gradiente de urbanización, denotando que la cuenca de aire urbana pudiera estar conectada con la rural. La estacionalidad mostró que la presencia de Zn, $\mathrm{Fe}, \mathrm{Cd}, \mathrm{Cu}, \mathrm{Ni}, \mathrm{Mn} \mathrm{Ca}$ y $\mathrm{Mg}$ es alta durante otoño, y K durante invierno. Los factores de enriquecimiento exponen que $\mathrm{Zn}$ y $\mathrm{Cd}$ se encuentran muy enriquecidos, $\mathrm{Cu}$ y $\mathrm{Ni}$ moderadamente enriquecidos y, $\mathrm{Ca}$, $\mathrm{K}$ y $\mathrm{Mn}$ no enriquecidos. Finalmente, las trayectorias para los vientos que arribaron a los sitios rurales revelan que sólo en Allende pudiera darse un arrastre de contaminantes durante verano, ya que las corrientes principales atraviesan la parte norte del AMM.
\end{abstract}

\section{ABSTRACT}

Bulk deposition was studied along an urbanization gradient in the state of Nuevo Leon, Mexico. During a yearlong period seven sites within the Metropolitan Area of Monterrey (MAM) and two rural sites (Allende and Linares) were monitored, with the purpose of characterizing deposition and identifying possible patterns between sites. A total of 32 rainfall events were collected. An average $\mathrm{pH}$ of $7.15 \pm 0.02$ was found, which indicates the presence of neutralizing substances in rainwater, as well as an average Electrical Conductivity of $153.96 \pm 6.83 \mu \mathrm{S} / \mathrm{cm}$. The annual accumulated deposition follows the descending order $\mathrm{Ca}>\mathrm{K}>\mathrm{Mg}>\mathrm{Fe}>\mathrm{Zn}>\mathrm{Mn}>\mathrm{Cu}>\mathrm{Cd}>\mathrm{Ni}$ and does not show significant differences between urban and rural areas, with the exception of $\mathrm{Ca}(\mathrm{p}=0.017)$. The Principal Component Analysis shows that metals $(\mathrm{Cu}, \mathrm{Zn}, \mathrm{Ni}, \mathrm{Mn}$, and $\mathrm{Cd})$ represent an important pathway in the deposition phenomena and this behavior is maintained through the urbanization gradient, which denotes that the rural areas could be connected to the air basin of the MAM. Seasonal deposition showed that $\mathrm{Zn}, \mathrm{Fe}$, $\mathrm{Cd}, \mathrm{Cu}, \mathrm{Ni}, \mathrm{Mn} \mathrm{Ca}$, and $\mathrm{Mg}$ are higher during autumn and $\mathrm{K}$ during winter. Enrichment Factors shows that $\mathrm{Zn}$ and $\mathrm{Cd}$ were highly enriched, $\mathrm{Cu}$ and $\mathrm{Ni}$ were moderately enriched, and $\mathrm{Ca}, \mathrm{K}$, and $\mathrm{Mn}$ were not enriched. Finally, backward trajectories for rural sites showed that only for Allende site a possible carry-over of pollutants is observed during the summer, since the wind currents come preferably from the northern part of the MAM.

Keywords: Bulk deposition, seasonal variations, urbanization gradient, metals, Principal Component Analysis. 


\section{Introduction}

Air pollution is a global problem that is principally caused by rapid demographic growth, uncontrolled urbanization, industrialization, high vehicle loads, and deforestation. These increase damage to the environment, which generates problems like ocean and soil acidification, ecosystem degradation, and threatens human health (Khaniabadi et al., 2017; Nowak et al., 2018). Emission sources can be of natural or anthropogenic origin and their adverse effects can reach local, regional, and global scales. The most common anthropogenic sources are industries, power plants, landfills, residential heating, and vehicles (Singh, 2017).

Atmospheric transport of pollutants occurs due to volatilized species and/or particles. Suspended particles (aerosol and dust) play an important role in the transport of pollutants around the environment, specifically those that have low volatility and aqueous solubility (Csavina et al., 2012). Deposition (dry or wet) of pollutants is an efficient mechanism for removing gases and particles from the atmosphere. Dry deposition is a mechanism of removal by turbulent transfer through gravitational settling onto a surface (land, water, buildings or plants) (Izquierdo and Avila, 2013). Wet deposition is dominated by two mechanisms: washout (below-cloud scavenging) and rainout (in-cloud scavenging) (Zheng et al., 2019). Dry and wet deposition vary from region to region, depending on the characteristics of air pollution (Anil, et al., 2017; Szép et al., 2017).

Suspended particulate matter in the atmosphere that contains a large variety of elements, can be deposited by wet or dry deposition, which together are called bulk deposition. Bulk deposition occurs when the collector sampler combines dry and wet deposition (Ma et al., 2019), the collector remains open throughout the sampling period. Bulk collectors, suitably located for daily inspection, can give results that are only $10-30 \%$ higher than those obtained with wet only collectors (Granat et al., 1996).

The deposition of major ions $\left(\mathrm{Na}^{+}, \mathrm{NH}_{4}{ }^{+}, \mathrm{K}^{+}\right.$, $\mathrm{Ca}^{2+}, \mathrm{Mg}^{2+}, \mathrm{Cl}^{-}, \mathrm{NO}_{3}{ }^{-}, \mathrm{SO}_{4}{ }^{2-}$ ) and metals has been studied in many urban and rural areas around the world (Facchini Cerqueira et al., 2014; Moreda-Piñeiro et al., 2017; Wright et al., 2018; Wu et al., 2018; Sharma and Kulshrestha, 2020). In the state of Nuevo Leon (NL) in northeastern Mexico, the Metropolitan Area of Monterrey (MAM) is one of the most industrialized, populous and contaminated cities in Mexico and Latin America (González et al., 2017). The accelerated industrial growth, together with the lack of urban planning, have resulted in serious air pollution problems in the MAM, mainly from ozone and particulate matter (Valdez Cerda et al., 2011). A few studies on rainfall deposition characteristics and mechanisms have been conducted in the recent past, yet they have only considered one sampling point within the MAM (Ramírez-Lara et al., 2016; Céron et al., 2018). The MAM does not have monitoring stations for wet or dry deposits; in fact, the only official network for monitoring atmospheric deposits in Mexico is located in the metropolitan area of Mexico City.

No study has been conducted so far to determine the possible dispersion of pollutants to rural areas surrounding the MAM. Moreover, there are no documented studies including as many monitoring points for this area of the country as the present study does.

The citrus region of the state, which is located in south-central NL, borders with the MAM. It is a region of great economic and cultural importance for the northeast of Mexico, where orange, tangerine and grapefruit have been produced for more than one hundred years and currently ranks fourth nationally as a citrus producer (Pantoja-Zaval and Flores-Vichi, 2018). The evaluation of elemental deposition and their possible sources of origin within the MAM and surrounding areas, specifically the citrus region, will aid in the improvement of air quality standards and the identification of possible effects on rural areas. In the present study, nine sites including urban and rural areas along an urbanization gradient were monitored during a year-long period. The main objectives were (1) to describe the characteristics of chemical element deposition by site and season and (2) to identify the deposition patterns among the nine monitoring sites and the comparison between urban and rural areas.

\section{Materials and Methods \\ 2.1 Study area}

This work was carried out in the MAM which is a highly urbanized area $(4,106,054$ inhabitants) 
(SEMARNAT, 2016), as well as a two rural areas in NL (Linares and Allende). The MAM has a semidry and warm climate, with an annual average precipitation of $623 \mathrm{~mm}$, mean temperature of $32^{\circ} \mathrm{C}$, with extreme temperatures during summer $\left(40^{\circ} \mathrm{C}\right)$ and winter $\left(-2^{\circ} \mathrm{C}\right)$ (Gobierno del Estado de Nuevo León, 2016). The urban areas are represented by different industrial activities such as metallurgy, chemistry, petrochemistry, pharmacy, textiles, ceramics, tannery, electronics, automobiles, aviation, building materials, machine manufacturing, iron and steel foundries, paper, asbestos, cement and wood (Valdez Cerda et al., 2011). The rural areas are classified as touristic and agricultural citrus areas (Alcalá Escamilla and López López, 2017). In the rural areas the climate is semi-warm and subhumid, with an average of 749 $\mathrm{mm}$ of summer rainfall; annual average temperature of $22^{\circ} \mathrm{C}$ in one site (Linares) and $15.8^{\circ} \mathrm{C}$ in the other (Allende), with an extreme maximum of $40.1^{\circ} \mathrm{C}$ and an minimum of $-2.4{ }^{\circ} \mathrm{C}$ (INAFED, 2010).

The MAM is composed of 13 municipalities, only 6 of which were sampled in this study (Santa Catarina, General Escobedo, Monterrey, Guadalupe, Cadereyta Jiménez, and San Nicolás). The municipalities of the rural area considered are Allende and Linares. The sampling points in the urban area (MAM) were placed within the environmental monitoring stations belonging to the state government of NL. Sampling points in the rural areas were placed within the educational facilities of the Autonomous University of Nuevo Leon. Sampling points in the rural areas were located near agricultural citrus orchards. Table I shows the location of the monitoring sites, the altitude, and the distance of the monitoring site to downtown Monterrey, considered as the central point from which the sampling starts along the urbanization gradient. Sampling within the metropolitan area was chosen with a preferential trend from the center to the south of the metropolitan area, taking only one point to the north (General Escobedo), in order to connect the MAM with the southern region of the state of Nuevo Leon, through the National Highway 85, which is an important access road within the state and for the MAM. It connects the south of the country with the MAM, allowing for important commercial exchange in the area and thus leading to a high load of vehicular traffic. The selected rural areas are regions of commercial importance for the state (Allende and Linares). In addition to the relevance of their agricultural and handicraft products, these are regions that have recreational areas for the population living within the MAM, which are frequently visited on weekends or holidays. The locations of each monitoring site and the municipalities that were considered to carry out the present study are shown in Figure 1.

\subsection{Sampling methods}

Deposition samples were collected with bulk samplers at each of the nine monitoring sites. The bulk samplers used in this study are described in Loya-Gonzalez et al. (2020). Three samplers were placed for each selected site on the roof of the environmental monitoring station with the aim of obtaining replications for each site. The monitoring period was a year-long from 30 January 2019 to 30 January 2020. The collection of samples was carried

Table I. Locations points of the monitoring sites, altitude, and distance to the MAM downtown.

\begin{tabular}{|c|c|c|c|c|c|}
\hline \multirow{2}{*}{$\begin{array}{l}\text { Point number } \\
\text { on the map }\end{array}$} & \multirow{2}{*}{$\begin{array}{l}\text { Names of the } \\
\text { monitoring sites }\end{array}$} & \multicolumn{2}{|c|}{ Coordinates } & \multirow{2}{*}{ Altitude (m) } & \multirow{2}{*}{$\begin{array}{c}\text { Distance to } \\
\text { downtown }(\mathrm{km})\end{array}$} \\
\hline & & Latitude (W) & Longitude (N) & & \\
\hline 1 & Escobedo & $25^{\circ} 48^{\prime \prime} 02^{\prime}$ & $100^{\circ} 20^{\prime \prime} 39^{\prime}$ & 528.61 & 14.71 \\
\hline 2 & Universidad & $25^{\circ} 43^{\prime \prime} 45^{\prime}$ & $100^{\circ} 18^{\prime \prime} 39^{\prime}$ & 516.97 & 6.44 \\
\hline 3 & Obispado & $25^{\circ} 40^{\prime \prime} 29^{\prime}$ & $100^{\circ} 20^{\prime \prime} 30^{\prime}$ & 589.01 & 3.26 \\
\hline 4 & Pastora & $25^{\circ} 40^{\prime \prime} 03^{\prime}$ & $100^{\circ} 14^{\prime} 53^{\prime}$ & 495.60 & 6.18 \\
\hline 5 & Pueblo Serena & $25^{\circ} 34^{\prime \prime} 33^{\prime}$ & $100^{\circ} 14^{\prime \prime} 54^{\prime}$ & 611.39 & 12.30 \\
\hline 6 & Santa Catarina & $25^{\circ} 40^{\prime \prime} 32^{\prime}$ & $100^{\circ} 27^{\prime} 53^{\prime}$ & 693.71 & 15.63 \\
\hline 7 & Cadereyta & $25^{\circ} 36^{\prime \prime} 02^{\prime}$ & $99^{\circ} 59^{\prime \prime} 44^{\prime}$ & 332.98 & 32.51 \\
\hline 8 & Allende & $25^{\circ} 17^{\prime \prime} 15^{\prime}$ & $100^{\circ} 00^{\prime \prime} 33^{\prime}$ & 438.92 & 52.16 \\
\hline 9 & Linares & $24^{\circ} 47^{\prime \prime} 45^{\prime}$ & $99^{\circ} 32^{\prime \prime 28}$ & 379.53 & 124.15 \\
\hline
\end{tabular}




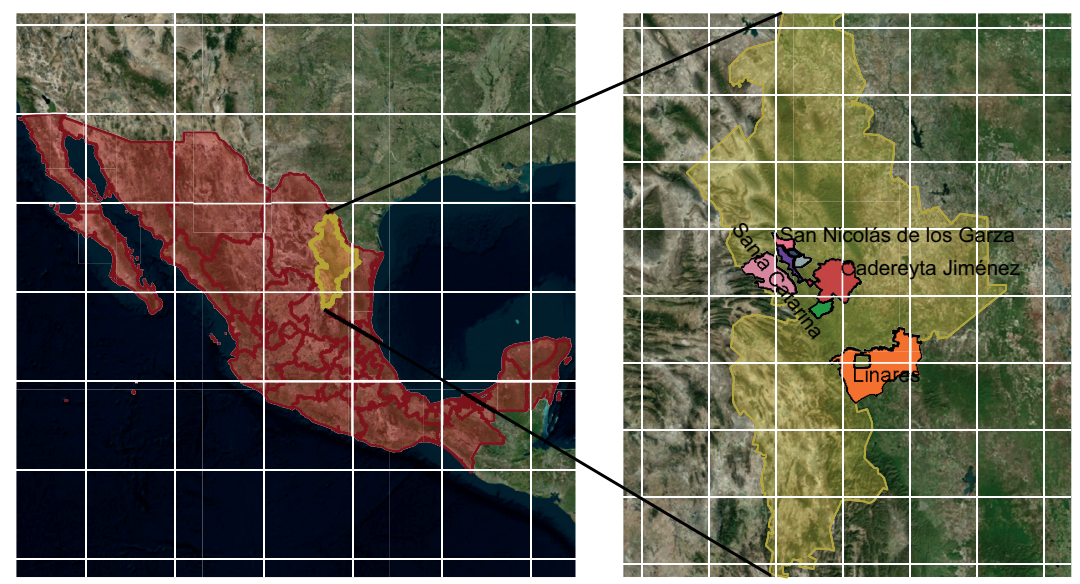

SYMBOLOGY

- Monitoring sites

Allende

Cadereyta Jimenez

General Escobedo

Guadalupe

Linares

Monterrey

San Nicolas de los Garza

Santa Catarina

Nuevo Leon

Mexico

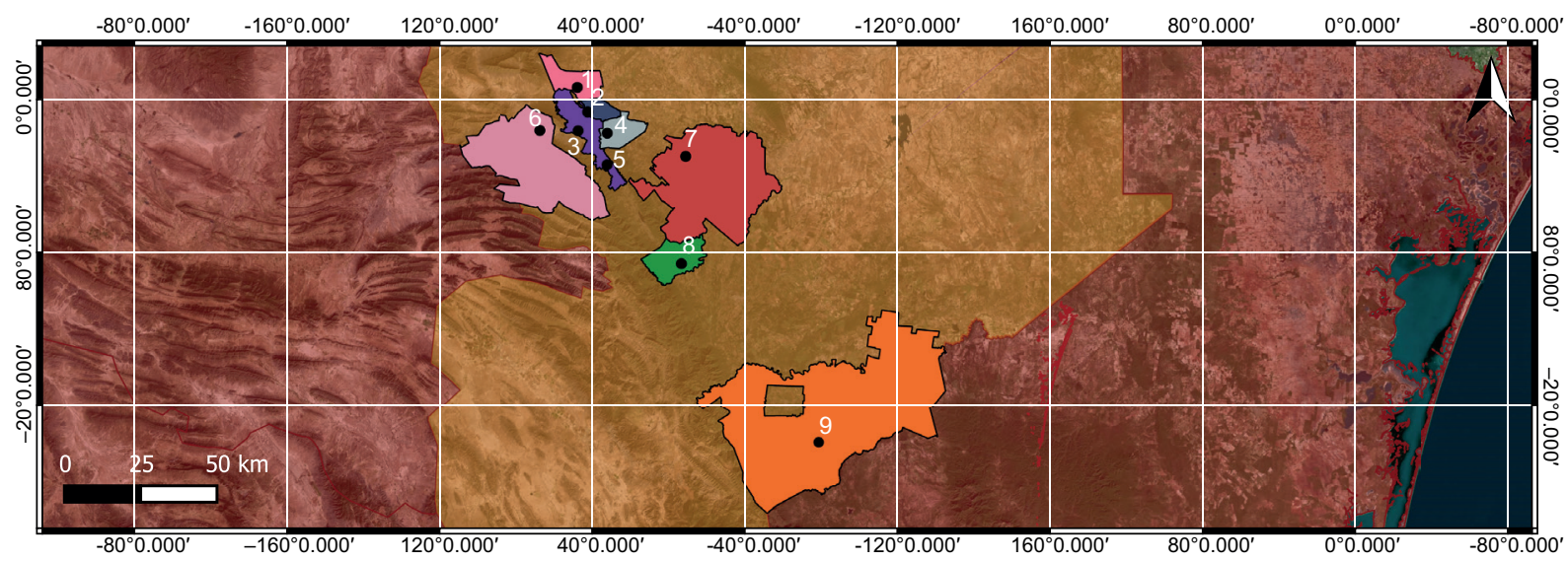

Fig. 1. Map of the study area and monitoring sites in the state of Nuevo Leon, Mexico.

out after each rain event, considering a singular rain event with eight hours of dry period between events (Yáñez-Díaz et al., 2014).

The $\mathrm{pH}$ and electric conductivity of the collected volume of rainwater was measured in situ using a digital meter Oakton 007072-75. A volume of $125 \mathrm{~mL}$ of rainwater was then transferred to a sterilized polyethylene bottle and were immediately placed in an ice chest for transport to the laboratory for further analysis. Samplers were then rigorously rinsed with deionized water several times, and then were placed again at their fixed sampling points. Rain events in which collectors did not obtain a minimum sample volume of $125 \mathrm{~mL}$ for chemical analysis, were discarded.

\subsection{Chemical analysis}

All rainwater samples were first filtered through Whatman ${ }^{\circledR}$ No. 42 filters to reduce the volume of suspended solids and to minimize risks of obstruction on the instrument suction system. Following the US EPA 3010A method, $50 \mathrm{~mL}$ of the sample were taken for acid digestion, in order to eliminate the organic matter present and thus proceed to the measurement of the selected elements $(\mathrm{Ca}, \mathrm{K}, \mathrm{Mg}$, $\mathrm{Mn}, \mathrm{Zn}, \mathrm{Fe}, \mathrm{Cu}, \mathrm{Ni}, \mathrm{Pb}, \mathrm{Cd}$ and $\mathrm{Cr}$ ). The rest of the sample was kept refrigerated at $4{ }^{\circ} \mathrm{C}$ for further analysis. For samples and solution standard preparation, 18.2 $\mathrm{M} \Omega$ water and ultrapure $\mathrm{HNO}_{3}$ were used. A mixed calibration solution-stock was prepared from single element solutions by Accu Standard in 1\% (v/v) $\mathrm{HNO}_{3}$. This stock was diluted for calibration of the MP-AES in the range $1-20 \mathrm{mg} \mathrm{L}^{-1}$ for $\mathrm{Ca}$ and 1 - $50 \mathrm{mg} \mathrm{L}^{-1}$ for $\mathrm{K}$ and $\mathrm{Mg}$. The determination of metals was performed by the procedure described in Loya-Gonzalez et al. (2020). Sample analysis was carried out on an atomic emission spectrometer 4200 MP-AES Agilent Technologies. The analytical cycle 
of the 4200 MP-AES thus consisted of 30 seconds sample uptake, 15 seconds to stabilize, then reading elements at preselected wavelengths and finally rinsing for 30 seconds with $1 \%(\mathrm{v} / \mathrm{v}) \mathrm{HNO}_{3}$. The regression analysis was performed for analytes, for which the result suggested acceptable data quality $\left(\mathrm{R}^{2}=0.996 ; \mathrm{p} \leq 0.01\right)$.

\subsection{Statistical analysis}

Deposition was calculated for each event as follows: multiplying the concentration of the measured element $\left(\mathrm{mg} \mathrm{L}^{-1}\right)$ obtained in the spectrophotometer by the volume (L) of sample collected, divided by the area occupied by the collector $\left(0.0398 \mathrm{~m}^{2}\right)$, then multiplied by a factor of 25 to bring everything to a square meter.

To estimate the annual accumulated deposition at each sampling site, a Shapiro-Wilk ( $p=95 \%)$ test was carried out to verify the assumptions of data distribution; $\mathrm{Cu}, \mathrm{Ni}, \mathrm{Mn}, \mathrm{Ca}$ and $\mathrm{K}$ were found to follow a normal distribution, while $\mathrm{Zn}, \mathrm{Fe}, \mathrm{Cd}$ and $\mathrm{Mg}$ did not. Therefore, to compare monitoring sites, and urban with rural areas a $T$ test was applied for the first group of elements and a Mann-Whitney $U$ Test $(\mathrm{p}=95 \%)$ for the rest.

To determine differences in deposition between monitoring sites, rainfall events, seasons of the year and areas (rural versus urban) a Kolmogorov-Smirnov test $(p=95 \%)$ was applied, finding that data did not follow a normal distribution. Thus, the use of the Kruskal-Wallis test was chosen $(p=95 \%)$, when significant differences were found a post hoc of Kruskal-Wallis was applied to identify the couples that differed between monitoring sites, rainfall events and seasons. A Spearman correlation analysis was performed to find the relationships between the elements and thus, try to understand the possible sources of the elements measured.

A factor analysis by principal components (PCA) was selected and applied to the complete data set to reduce number of variables and gain insight. PCA was also carried out for each season of the year, in order to determine whether elements that make up the main components changed with seasons (González et al. 2018). The statistical analyses were performed using the SPSS ${ }^{\circledR}$ software (Statistical Package for Social Sciences, version 22 for Windows, SPSS Inc., Chicago, IL) and the RStudio(C software (RStudio, version 1.2.5033 for Windows, 2009-2019, RStudio, Inc.).

\subsection{Enrichment Factor (EF)}

Enrichment Factors (EF) have been used since the 70 's to discriminate between oceanic, terrestrial, and potentially other elemental sources in the atmosphere of remote regions (Ediagbonya 2016). Considering that the existing variation in the concentration of a given element on the environment is due to its natural lithological composition, the presence of it in quantities greater than its concentration in the crust suggests the influence of anthropogenic activities. Therefore, the EFs are calculated by normalizing the values found in the atmosphere to a conservative element (regularly $\mathrm{Al}$ and $\mathrm{Fe}$ for metals and $\mathrm{Ca}$ for larger ions), which is one that will be influenced almost exclusively by sources from the crust (Cable and Deng, 2018).

With the aim of knowing the possible sources of origin of the elements analyzed in the present study, the EF was calculated taking $\mathrm{Fe}$ as a conservative element for metals and $\mathrm{Ca}$ for the larger ions $(\mathrm{Ca}, \mathrm{K}$ and $\mathrm{Mn}$ ). The EF was calculated based on Equation 1.

$E F=\frac{\left(\frac{X}{F_{e}}\right) \text { sample }}{\left(\frac{X}{F_{e}}\right) \text { crust }}$

where $(X / F e)$ sample is the ratio of bulk deposition of a given element in the sample, while $(\mathrm{X} / \mathrm{Fe})$ crust is the concentration ratio of the given element in the continental crust; elemental concentrations in the crust were obtained from Mason and Moore (1982). For the sample ratio, the $\mathrm{Fe}$ and $\mathrm{Ca}$ average concentrations for the Linares site was used as reference concentration due to the minor presence of sources of contamination near to the monitoring site.

EF values close to one for an element suggest that the crust material is a major source of this element. In practice, however, elements with values in the range 1 to 10 are not enriched in the atmosphere, implying a source from the crust. Elements with EF values in the range of 10 to 500 are considered moderately enriched, indicating higher concentrations of a particular element in atmospheric samples than would be expected from crust material. Finally, EF values higher than 500 showed highly enriched conditions, 
indicating strong anthropogenic contribution ( $\mathrm{Wu}$ et al. 2018).

\subsection{Backward trajectories}

To identify the possible origin of the air masses that reached the rural areas (Linares and Allende) during the rain events analyzed for the period of January 2019-January 2020, air mass trajectories were tracked, taking as reference the rainfall events during two seasons of the year (winter and summer) and a monitoring point in the sites, taking into account 24 $\mathrm{h}$ before the rain event and the prevailing conditions during the rain event. The Hybrid Single-Particle Lagrangian Integrated Path Model (HYSPLIT) was used to determine back trajectories, based on $1^{\circ} \times 1^{\circ}$ meteorological data (GDAS - Global Data Assimilation System) at 100, 500 and 1000 Above Ground Level (AGL).

\section{Results and Discussion}

\subsection{Precipitation}

A total of 422 rainwater samples were collected in 32 rain events totaling $448 \mathrm{~mm}$ of rainfall in the MAM, $532 \mathrm{~mm}$ in Linares and $782 \mathrm{~mm}$ in Allende during the one-year period (Fig. 2a). Most of the rain events sampled correspond to accumulated precipitation of less than $50 \mathrm{~mm}(90 \%)$; the highest precipitation event of the year corresponded to tropical storm Fernand (3-6 September 2019). This is a consistent finding at study sites located in semi-arid areas. Nevertheless, the average accumulated precipitation for these three areas in the last 30 years is higher than found in the present study for 2019, in which rains were scarce and tropical storm Fernand favored the increase in the annual accumulated precipitation (CONAGUA, 2020). The months with the highest number of rainfall events were March, September, and October. The monthly accumulated precipitation was higher in September, due to the influence of tropical storm Fernand. The average of a rain event was $28.62 \pm 2.57 \mathrm{~mm}$, with a minimum value of $1.18 \mathrm{~mm}$ (site Linares) and a maximum value of $251.51 \mathrm{~mm}$ (all sites during Fernand storm). Fall was the season with the highest precipitation volume registered in this study, which is consistent with the regular rainy season for the region's climate type.

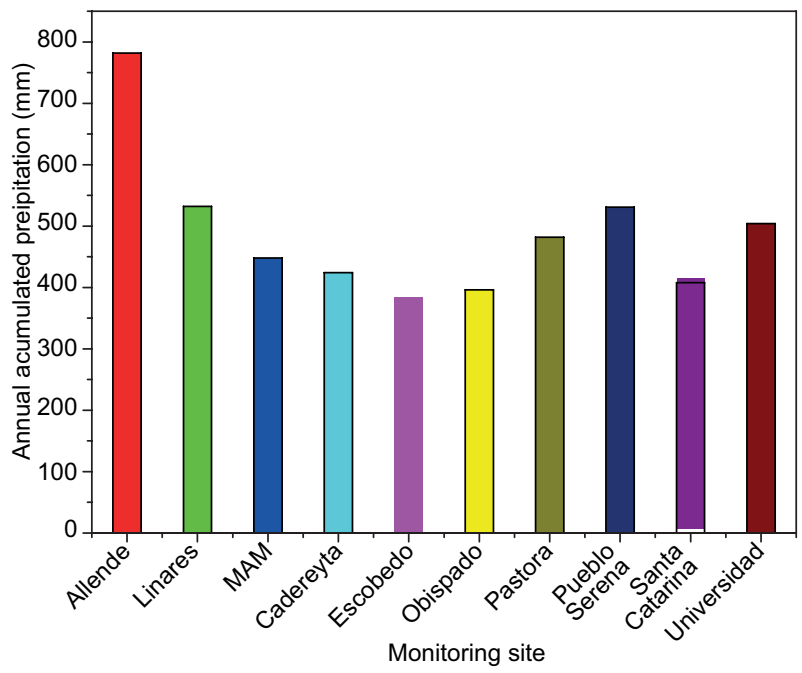

Fig. 2a. Annual accumulated precipitation by site, including the average annual accumulated precipitation in the MAM.

The trends of the monthly accumulated precipitation by monitoring site and the average monthly temperature can be seen in Figure 2b. No rain events are shown in the month of December because rain events only occurred between December 21 and 30. However, the rain recorded on those days was below $0.1 \mathrm{~mm}$, on average, which was not enough to perform the chemical analysis. For this reason, no data points are presented for the month of December. The dominant annual winds for the MAM are from the east-northeast

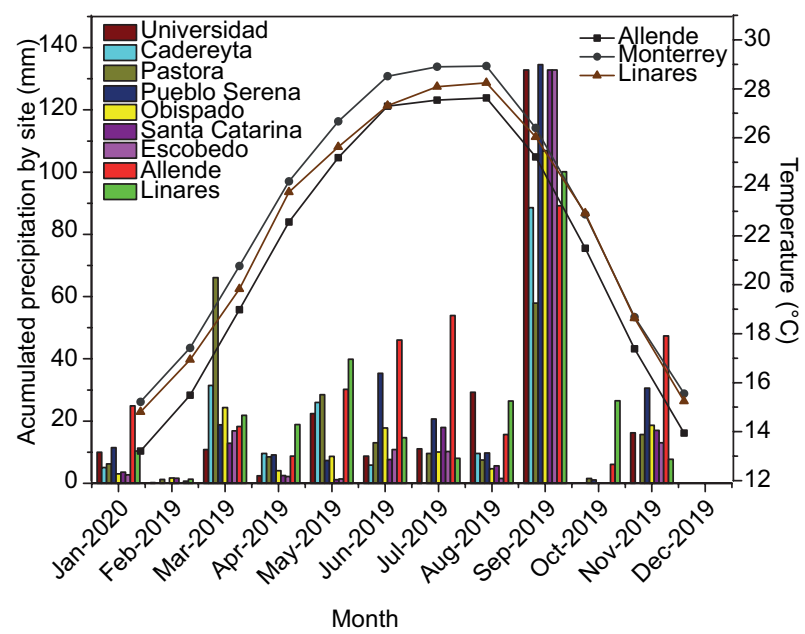

Fig. 2b. Monthly accumulated precipitation ( $\mathrm{mm}$ ) by monitoring site (vertical bars, left axis) and average monthly air temperature $\left({ }^{\circ} \mathrm{C}\right.$, lines and right axis). 
and southeast (Loya-Gonzalez et al., 2020), and for the rural areas from the east and southeast.

\subsection{Electrical conductivity and $p H$}

Figure 3 shows the average $\mathrm{pH}$ and electrical conductivity (EC) by month for each monitoring site, the minimum $\mathrm{pH}$ value observed was 5.90 (site Pastora) and the maximum 9.96 (site Linares), with an average of $7.15 \pm 0.02$. A higher value than the widely accepted background rainfall $\mathrm{pH}$ of 5.6 (Charlson and Rodhe, 1982), was to be expected because the predominant soil type in the region is Calcisol. The results obtained are consistent with those reported by other studies for the MAM (Ramírez-Lara et al., 2016) as well as with those reported by other studies showing that rainfall has alkaline $\mathrm{pH}$ in this region (Alves et al., 2018). The lowest $\mathrm{pH}$ values (5.90) were observed during the spring and the highest values (9.96) during the fall. The minimum values differ from a previous study that reported the lowest values in summer (Ramírez-Lara et al., 2016).
The EC shows an average of $153.96 \pm 6.83 \mu \mathrm{S} / \mathrm{cm}$, with a minimum value of $10 \mu \mathrm{S} / \mathrm{cm}$ (during tropical storm Fernand in September for all sites) and a maximum value of $814 \mu \mathrm{S} / \mathrm{cm}$ (during May in site Pastora). These values display a wide range, probably due to the prevailing atmospheric composition before and during a rainfall event, with changes depending on atmospheric dynamics. In contrary with $\mathrm{pH}, \mathrm{EC}$ shows lowest $(10 \mu \mathrm{S} / \mathrm{cm})$ values during the fall, coinciding with the rainy season for the state. This may be due to a possible dilution of the ions present in the rain due to the greater precipitation in this season. Highest $(814 \mu \mathrm{S} / \mathrm{cm})$ electrical conductivity values were observed during spring, which also coincides with a season of scarce rain, with an exception for March which presented a high number of rain events.

The results of the Kruskal-Wallis tests applied to all the data (including all samples) indicate that the $\mathrm{pH}$ values did not show significant differences among the monitoring sites $(\mathrm{p}=0.86)$ nor between the urban and rural areas $(\mathrm{p}=0.500)$, but there were significant

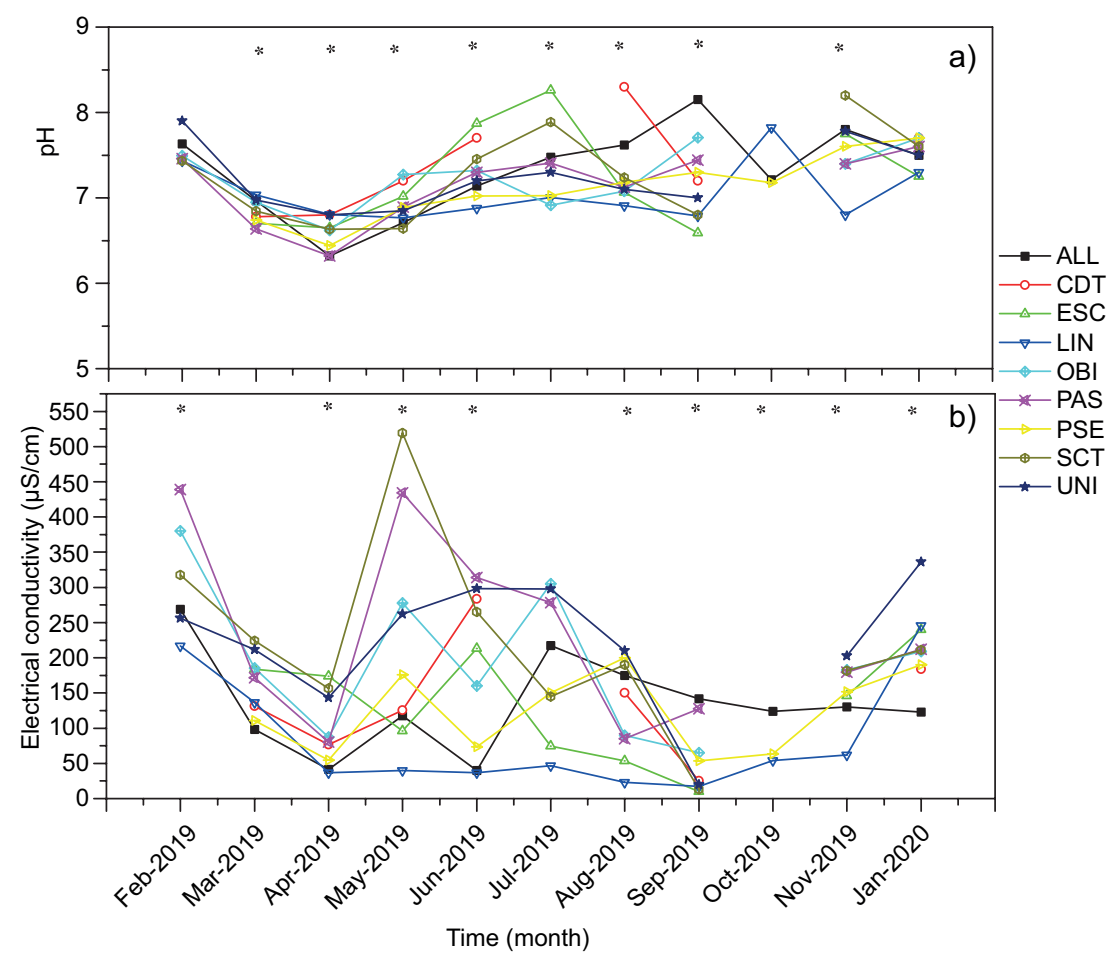

Fig. 3. a) $\mathrm{pH}$ and b) electrical conductivity $(\mathrm{mS} / \mathrm{cm})$ monthly mean values for each monitoring site. Within each graph, asterisks $\left({ }^{*}\right)$ denote significant $(\mathrm{p}<0.05)$ differences among sites in $\mathrm{pH}$ or electrical conductivity according to the Kruskal-Wallis test. 
differences $(\mathrm{p} \leq 0.05)$ for the season of the year as well as the rainfall events. Post hoc Kruskal-Wallis test showed significant differences in $\mathrm{pH}$ values for the seasons, all seasons differ from each other $(\mathrm{p}<0.05)$, except for summer compared to autumn. In addition, significant differences between rain events were observed, where the events that stand out are March 28, April 1, and September 10, 2019. This may be due to the fact that during the months of March and September the amount of precipitation was greater than for the rest, therefore a lower $\mathrm{pH}$ value was found during these events due to a dilution effect.

Significant differences in EC values were observed $(p \leq 0.05)$ between monitoring sites and rainfall events except for March and July, as can be observed in Figure 3 (b). Post hoc Kruskal-Wallis test showed significant differences for EC values between rainfall events, and the tropical storm Fernand event was significantly different to the rest. Also, monitoring sites Santa Catarina and Obispado were different from Allende, because Allende is a rural site with less industrial activity or traffic compared to Obispado and Santa Catarina sites in the MAM. Significant differences were observed between urban and rural areas due to different sources, with less anthropogenic emissions in rural areas. Post hoc test for seasons showed differences for all seasons, except for the combination spring-summer, in which the precipitation amount was scarce, the temperature was higher, and calm winds were more prevalent. In contrast, winter and autumn present more precipitation dates and amounts, stronger winds, and are influenced by the passage of cold fronts.

\subsection{Individual rainfall event deposition analysis}

The individual rainfall events were analyzed in order to detect differences among them and monitoring sites. The Kruskal-Wallis test shows significant differences for all elements analyzed between rainfall events and per monitoring site $(\mathrm{p} \leq 0.05)$. Likewise, rainfall events show significant diferences between the urban and rural areas for $\mathrm{Cd}, \mathrm{Fe}, \mathrm{Ni}$ and $\mathrm{Ca}$ $(\mathrm{p} \leq 0.05)$, but not for $\mathrm{Zn}(\mathrm{p}=0.654), \mathrm{Cu}(\mathrm{p}=0.296)$, $\mathrm{Mn}(\mathrm{p}=0.579), \mathrm{K}(\mathrm{p}=0.537)$ and $\mathrm{Mg}(\mathrm{p}=0.094)$; the post hoc Kruskal-Wallis test performed for rainfall events found that those corresponding to tropical storm Fernand showed differences in all elements with respect to other rainfall events. Results of a post hoc test between monitoring sites are shown in Table II. Remarkably, Fe in the Linares site was different from Universidad, due to Linares site being a rural site surrounded by natural vegetation. On the other hand, Universidad site is very close to emission sources like the metallurgical industries. Also, other sites (Escobedo, Santa Catarina and Pueblo Serena) inside the MAM were different to Universidad site in terms of Fe deposition. This can indicate that these sites were not influenced by the emission sources that affect the Universidad site. Aditionally, Linares site shows differences in $\mathrm{Zn}$ and $\mathrm{Ca}$ deposition with respect to the urban sites, and the reason why concentrations in Linares were used as baseline concentrations in the calculation of EF. Figure 4 shows the distribution of the average deposition by each rainfall event. It should be noted that deposition increased on September 07, due to tropical storm Fernand.

\subsection{Annual accumulated element deposition}

The average annual accumulated deposition of the elements analyzed in this study is shown in Table III. The average fluxes $\left(\mathrm{mg} \mathrm{m}^{-2}\right.$ year $\left.^{-1}\right)$ for all monitoring sites are placed in the following descending order $\mathrm{Ca}>\mathrm{K}>\mathrm{Mg}>\mathrm{Fe}>\mathrm{Zn}>\mathrm{Mn}>\mathrm{Cu}>\mathrm{Cd}>\mathrm{Ni}$. It should be noted that lead and chromium measurements were carried out finding concentrations below the detection limit of the method used, for which they were not quantifiable.

The Mann Whitney U test showed no significant differences between the nine monitoring sites for the annual accumulated deposition of $\mathrm{Zn}, \mathrm{Fe}, \mathrm{Cd}$ and $\mathrm{Mg}(\mathrm{p}=0.317$ for all elements). Also, the Mann-Whitney U test shows no significant differences between the urban and rural areas in the annual deposition for $\mathrm{Zn}(\mathrm{p}=1), \mathrm{Fe}(\mathrm{p}=0.333), \mathrm{Cd}(\mathrm{p}=0.222)$, and $\mathrm{Mg}$ ( $p=0.889)$. In turn, the $T$ test applied to the rest of the elements $(\mathrm{Cu}, \mathrm{Ni}, \mathrm{Mn}, \mathrm{Ca}$ and $\mathrm{K})$ showed significant differences between monitoring sites $(\mathrm{p} \leq 0.05$ for all elements) and no differences when urban and rural areas where compared, $\mathrm{K}(\mathrm{p}=0.115), \mathrm{Cu}(\mathrm{p}=$ $0.096), \mathrm{Mn}(\mathrm{p}=0.052), \mathrm{Ni}(\mathrm{p}=0.097)$ with exception of $\mathrm{Ca}(\mathrm{p}=0.017)$. González et al. (2016) have shown that high concentrations of $\mathrm{Ca}$ are found in the MAM emitted by local construction industries and the exploitation of rich deposits of Calcite.

The trend of the annual accumulated deposition by monitoring site and element is illustrated in Figure 5. 
Table II. Results of Post hoc Kruskal-Wallis test with Bonferroni correction for the elements that show significant differences between monitoring sites.

\begin{tabular}{lcrc}
\hline Site 1-Site2 & Element & Test statistic & Adj. Sig. \\
\hline Linares-Allende & $\mathrm{Zn}$ & 85.267 & 0.005 \\
Linares-Universidad & $\mathrm{Zn}$ & -107.085 & 0.001 \\
Escobedo-Universidad & $\mathrm{Zn}$ & -102.496 & 0.012 \\
Santa Catarina-Universidad & $\mathrm{Zn}$ & -99.922 & 0.010 \\
Santa Catarina-Allende & $\mathrm{Cd}$ & 98.761 & 0.010 \\
Linares-Universidad & $\mathrm{Fe}$ & -112.157 & 0.000 \\
Escobedo-Universidad & $\mathrm{Fe}$ & -109.321 & 0.005 \\
Santa Catarina-Universidad & $\mathrm{Fe}$ & -99.674 & 0.010 \\
Pueblo Serena-Universidad & $\mathrm{Fe}$ & -84.181 & 0.048 \\
Santa Catarina-Universidad & $\mathrm{Cu}$ & -88.392 & 0.047 \\
Santa Catarina-Allende & $\mathrm{Ni}$ & 88.492 & 0.019 \\
Escobedo-Allende & $\mathrm{Ni}$ & 85.512 & 0.048 \\
Escobedo-Allende & $\mathrm{Mn}$ & 88.096 & 0.034 \\
Escobedo-Universidad & $\mathrm{Mn}$ & -94.387 & 0.034 \\
Linares-Allende & $\mathrm{Ca}$ & 88.599 & 0.004 \\
Linares-Cadereyta & $\mathrm{Ca}$ & 11.044 & 0.001 \\
Linares-Universidad & $\mathrm{Ca}$ & -124.615 & 0.000 \\
Santa Catarina-Pastora & $\mathrm{K}$ & 95.85 & 0.005 \\
Pueblo Serena-Pastora & $\mathrm{K}$ & 89.856 & 0.006 \\
Escobedo-Universidad & $\mathrm{Mg}$ & -110.089 & 0.004 \\
Linares-Universidad & $\mathrm{Mg}$ & -108.923 & 0.000 \\
Santa Catarina-Universidad & $\mathrm{Mg}$ & -95.823 & 0.018 \\
Pueblo Serena-Universidad & $\mathrm{Mg}$ & -94.032 & 0.012 \\
\hline
\end{tabular}

Asymptotic meanings are shown (two-tailed tests). The significance level is 0.05

Notice that the annual deposition trend of metals is similar between monitoring sites, despite the great difference among the urbanization characteristics of sites and distance between them. Rural areas may be connected to the air basin of the MAM due to similarities in metal composition. Despite the fact that $\mathrm{Fe}$ and $\mathrm{Zn}$ deposition are higher at the Universidad site, the Mann Withney U test does not detect significant differences between this site and the rest, as previously mentioned. The high value of $\mathrm{Fe}$ and $\mathrm{Zn}$ may be due to the proximity of the Universidad site to metallurgical industries, that are one of the most important industrial activities in the region. In a previous study it was found that $\mathrm{Fe}$ was one of the main elements deposited via atmosphere at Universidad site, which was also determined in this study (Céron et al., 2018).

It was expected to find the highest presence of Calcium due to the geochemical origin of the region. The predominance of Calcium in wet deposition flows has already been reported in a previous study (Ramírez-Lara et al., 2016), where it was concluded that Calcium suggests a significant contribution from the earth's crust, which is reasonable because of the Calsisol soils dominant type in the MAM. This can also be related to the neutral $\mathrm{pH}$ found in this study as we can see in Figure 3. Moreover, industrial activity or exploitation of quarries are an important activity in the MAM, as already mentioned. The high presence of Zinc may be due to local industrial emissions sources and traffic within the urban area, that could even be affecting rural areas as well. A recent study reports that in wet deposition flows, the Zinc values may be relatively higher due to major solubility compared to the other chemical species (Siudek and Frankowski, 2017).

In order to know the possible origin of the elements studied, an Enrichment Factor (EF) was calculated taking as conservative elements $\mathrm{Fe}$ for metals and $\mathrm{Ca}$ for the major ions, the results of 


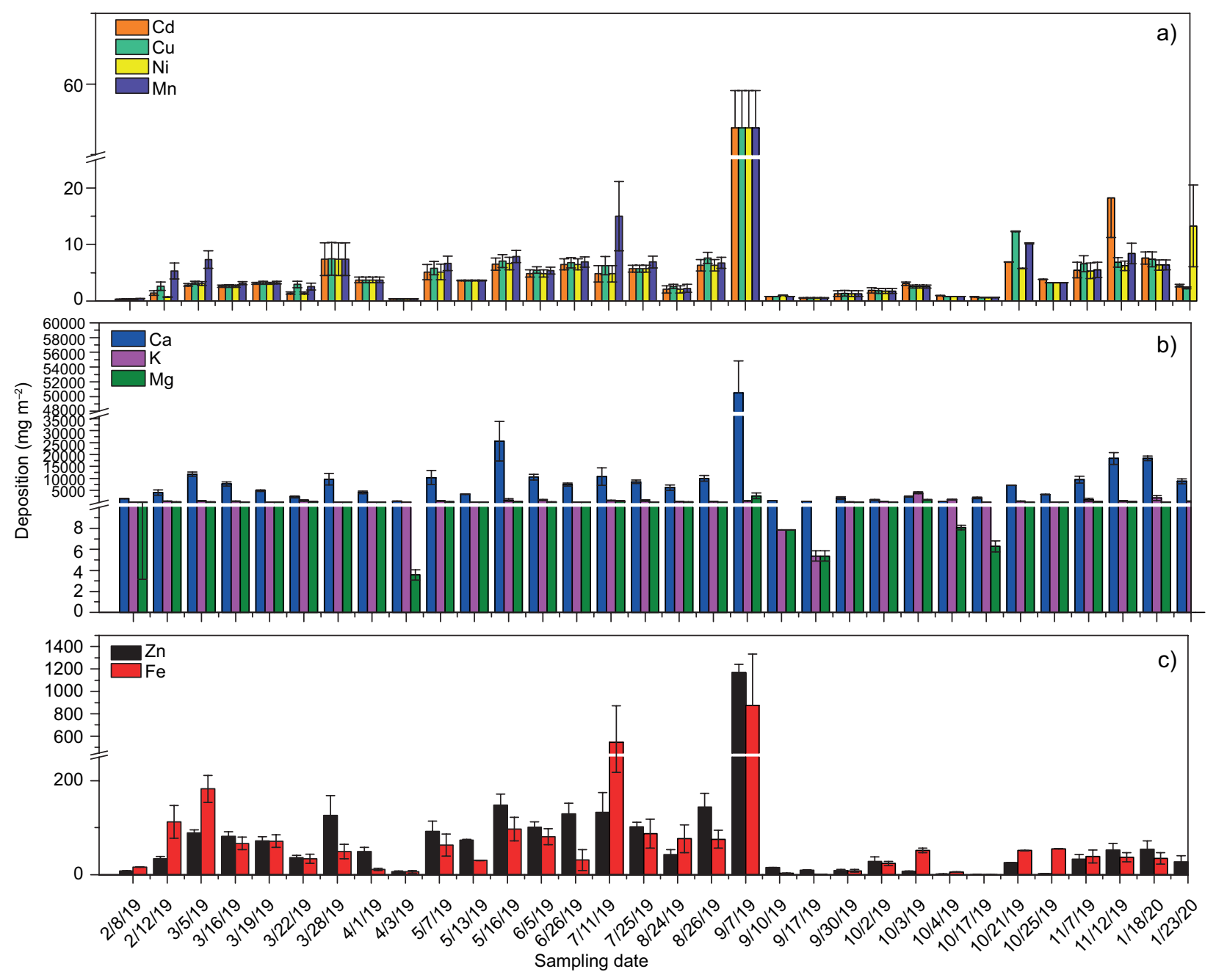

Fig. 4. Deposition by rainfall event a) $\mathrm{Cd}, \mathrm{Cu}, \mathrm{Ni}$ and $\mathrm{Mn}$, b) $\mathrm{Ca}, \mathrm{K}$ and $\mathrm{Mg}$, and c) $\mathrm{Zn}$ and Fe.

Table III. Average annual accumulated deposition $\left(\mathrm{mg} \mathrm{m}^{-2}\right.$ year $\left.^{-1}\right)$ by chemical elements.

\begin{tabular}{crrrrrr}
\hline Elements & \multicolumn{1}{c}{ Mean } & \multicolumn{1}{c}{ EE } & \multicolumn{1}{c}{ SD } & Minimum & Maximum & \multicolumn{1}{c}{ Median } \\
\hline $\mathrm{Ca}$ & 202871.38 & 18996.97 & 56990.92 & 124959.89 & 291503.29 & 188566.57 \\
$\mathrm{~K}$ & 10062.34 & 2041.42 & 6124.25 & 2884.37 & 20138.38 & 10415.87 \\
$\mathrm{Mg}$ & 5406.17 & 1920.06 & 5760.17 & 1538.20 & 19696.12 & 3528.58 \\
$\mathrm{Zn}$ & 2395.98 & 240.52 & 721.55 & 1737.52 & 4078.08 & 2227.54 \\
$\mathrm{Fe}$ & 2640.22 & 992.96 & 2978.88 & 538.45 & 8686.32 & 1375.04 \\
$\mathrm{Mn}$ & 151.49 & 15.33 & 46.00 & 101.57 & 239.38 & 140.01 \\
$\mathrm{Cu}$ & 136.34 & 10.02 & 30.06 & 102.81 & 199.30 & 132.69 \\
$\mathrm{Cd}$ & 134.09 & 14.17 & 42.50 & 97.29 & 212.41 & 123.02 \\
$\mathrm{Ni}$ & 131.15 & 10.69 & 32.07 & 95.90 & 195.60 & 126.79 \\
\hline
\end{tabular}

The total number of data was nine for all the elements.

$\mathrm{SD}=$ standard deviation.

$\mathrm{EE}=$ standard error. 

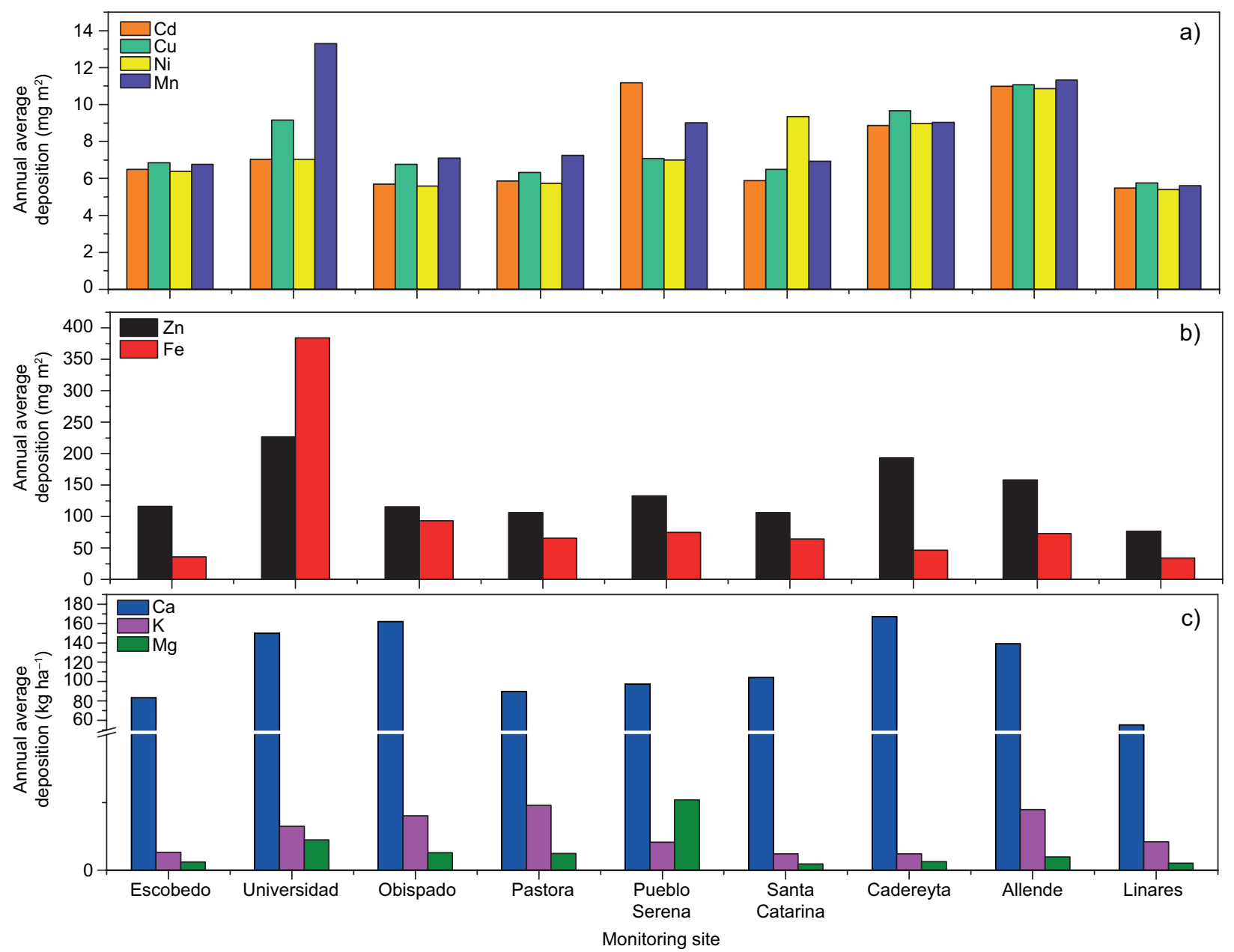

Fig. 5. Element annual average deposition by monitoring site. a) $\mathrm{Cd}, \mathrm{Cu}, \mathrm{Ni}$ and $\mathrm{Mn}, \mathrm{b}) \mathrm{Zn}$ and $\mathrm{Fe}, \mathrm{c}) \mathrm{Ca}, \mathrm{K}$ and $\mathrm{Mg}$.

EF by each site are shown in Table IV. It can be observed that $\mathrm{K}$ and $\mathrm{Mg}$ showed values lower than one, so these elements are related to crustal material sources. In other hand, Mn shows values between 1 to 10 for all the sites, which is also related to crustal/ soil material, but not for the Universidad and Santa Catarina sites (16.75 and 10.76 respectively), which may indicate a slight enrichment for the element in these sites of the MAM. The highest EF values were reached by $\mathrm{Zn}$ and $\mathrm{Cd}$ in all the sites, which are in a range greater than $500 \mathrm{EF}$ values, which indicates a highly enriched condition, due to human activities. Finally, in a moderately enrichment value was found for $\mathrm{Cu}$ and $\mathrm{Ni}$ (values ranged from 50 to 210) for all sites, due to a certain antropogenic influence. The enrichment factor for $\mathrm{Fe}$ and $\mathrm{Ca}$ could not be obtained because these elements were selected as a conservative element for all calculations, however, it can be highlighted that during the post hoc tests of the deposition values per event compared between sites it was observed that the deposition of $\mathrm{Fe}$ and $\mathrm{Ca}$ in Linares was significantly different and lower than the Universidad site for example, which is strongly influenced by antropogenic emissions, as explained in section 3.3 of the manuscript.

\subsection{Distribution patterns of elements deposition and PCA analysis}

With the purpose of recognizing distribution patterns of the elements through the monitoring sites and the possible source from which they come from, the correlation between the elements was analyzed and a factorial analysis of reduction of dimensions by principal components was used. In pollution 
Table. IV. Enrichment Factors (EF) for each site by element, considering as conservative elements $\mathrm{Fe}$ (for metals) and $\mathrm{Ca}$ (for major ions).

\begin{tabular}{|c|c|c|c|c|c|c|c|}
\hline \multirow{2}{*}{ Monitoring site } & \multicolumn{7}{|c|}{ Enrichment Factors (FE) } \\
\hline & $\mathrm{Zn}$ & $\mathrm{Cd}$ & $\mathrm{Cu}$ & $\mathrm{Ni}$ & $\mathrm{Mn}$ & $\mathrm{K}$ & $\mathrm{Mg}$ \\
\hline Allende & 984.17 & 22622.82 & 82.85 & 59.63 & 5.09 & 0.10 & 0.03 \\
\hline Linares & 918.66 & 23707.35 & 90.59 & 61.25 & 5.24 & 0.22 & 0.04 \\
\hline Universidad & 2589.76 & 22661.39 & 230.74 & 63.74 & 16.75 & 0.43 & 0.25 \\
\hline Escobedo & 1109.85 & 22844.67 & 98.24 & 59.63 & 5.17 & 0.09 & 0.05 \\
\hline Obispado & 1682.87 & 28123.97 & 209.23 & 63.76 & 10.01 & 0.40 & 0.17 \\
\hline Pastora & 1342.14 & 23017.24 & 121.38 & 59.86 & 9.55 & 0.72 & 0.18 \\
\hline Santa Catarina & 1540.25 & 22775.78 & 121.88 & 130.56 & 10.76 & 0.16 & 0.10 \\
\hline Pueblo Serena & 1306.32 & 31300.28 & 87.57 & 59.63 & 7.95 & 0.13 & 0.07 \\
\hline Cadereyta & 1273.91 & 22769.32 & 104.19 & 62.43 & 5.06 & 0.07 & 0.04 \\
\hline
\end{tabular}

Note: The average concentrations at Linares site was considered for the calculation of the sample fraction, the concentrations of elements in the crust was obtained from literature.

analysis, the correlations between two metals regularly indicates that these elements come from the same source when the correlation is positive, while a negative correlation shows that they come from different sources (Naifar et al., 2018; Chen et al., 2019). The correlations showed to be significant between the elements analyzed, finding a high positive correlation for $\mathrm{Cd}-\mathrm{Cu}, \mathrm{Cd}-\mathrm{Ni}, \mathrm{Cd}-\mathrm{Mn}, \mathrm{Cu}-\mathrm{Ni}, \mathrm{Cu}-\mathrm{Mn}$ and $\mathrm{Ni}-\mathrm{Mn}$. In addition to this, the rest of the elements showed medium to low positive correlations, as observed in Table V. Also precipitation amount shown a highly positive correlation with all the metals (at 0.78 to 0.98 ).
$\mathrm{Fe}$ is poorly correlated with the rest of the elements, as Fe regularly comes from materials in the earth's (Céron et al., 2018) this can be the reason of the poorly correlation, but in this study some sites are very close to metallurgic industries and others are in non industrial regions, due to the high differences in emission sources between the monitoring sites is possible that $\mathrm{Fe}$ was weakly correlated with other metals. The rest of the elements that showed strong correlations come from common anthropogenic sources, such as industrial and vehicular emissions. Depositions of $\mathrm{Cd}, \mathrm{Cu}$ and $\mathrm{Ni}$ are attributed in various studies to the coal industries (Chen et al., 2019;

Table. V. Spearman correlations coefficients for the bulk deposition of chemical elements (high correlations $>0.8$ are shown in bold).

\begin{tabular}{|c|c|c|c|c|c|c|c|c|c|c|}
\hline & PREC & $\mathrm{Zn}$ & $\mathrm{Cd}$ & $\mathrm{Fe}$ & $\mathrm{Cu}$ & $\mathrm{Ni}$ & $\mathrm{Mn}$ & $\mathrm{Ca}$ & K & $\mathrm{Mg}$ \\
\hline PREC & & $.759 * *$ & $.989 * *$ & $.364 * *$ & $.913 * *$ & $.986 * *$ & $.855 * *$ & $.782 * *$ & $.272 * *$ & $.517 * *$ \\
\hline $\mathrm{Zn}$ & & & $.731 * *$ & $.575^{* *}$ & $.739 * *$ & $.732 * *$ & $.778 * *$ & $.664 * *$ & $.311 * *$ & $.501 * *$ \\
\hline $\mathrm{Cd}$ & & & & $.355^{* *}$ & $.905 * *$ & $.977 * *$ & $.857 * *$ & $.783 * *$ & $.287 * *$ & $.530 * *$ \\
\hline $\mathrm{Fe}$ & & & & & $.406^{* *}$ & $.346^{* *}$ & $.605^{* *}$ & $.476^{* *}$ & $.435^{* *}$ & $.461 * *$ \\
\hline $\mathrm{Cu}$ & & & & & & $.900 * *$ & $.881 * *$ & $.803^{* *}$ & $.424 * *$ & $.653^{* *}$ \\
\hline $\mathrm{Ni}$ & & & & & & & $.844 * *$ & $.790 * *$ & $.259 * *$ & $.50 * *$ \\
\hline Mn & & & & & & & & $.796^{* *}$ & $.461 * *$ & $.692 * *$ \\
\hline $\mathrm{Ca}$ & & & & & & & & & $.475^{* *}$ & $.618^{* *}$ \\
\hline K & & & & & & & & & & $.735 * *$ \\
\hline $\mathrm{Mg}$ & & & & & & & & & & \\
\hline
\end{tabular}

** Correlation is significant at the 0.01 level (2 tails).

$\mathrm{PREC}=$ precipitation amount 
Chia-Te et al., 2019), which is not applicable to this study. However, the metallurgical industry is one of the main activities carried out within the MAM and it should be the most likely source of emission for these highly correlated elements (Valdez Cerda et al., 2011; Céron et al., 2018; González et al., 2017). Mn has been attributed to industrial sources; reports showed that the presence of $\mathrm{Mn}$ in the atmosphere is related to metal-mechanical industries. As already mentioned, the MAM has extensive metallurgical industrial activity that can contribute Mn emissions (Quiterio et al., 2004; Zhou et al., 2014; González et al., 2017).

PCA was applied to identify which elements have the greatest influence on deposition. Metals are grouped in the first component, explaining most of the variance of the phenomenon studied. The matrix used for the PCA analysis consisted of 422 observations and 11 variables. Components with axis in values $>1$ were selected, from which two components were obtained, together explaining $74.88 \%$ of the total variance. The load graphic shows the grouping of elements within the two main components obtained, to explain deposition in a simple way (Figure 6).

The CP1 has the greatest weight on the variability of the data. It explains $58.49 \%$ of the variance and it is made up of metals such as $\mathrm{Cu}, \mathrm{Zn}, \mathrm{Ni}, \mathrm{Mn}$ and $\mathrm{Cd}$. This component suggests that the origin of these elements can be related to vehicular and industrial emissions (McKenzie et al., 2009; Céron et al., 2018;

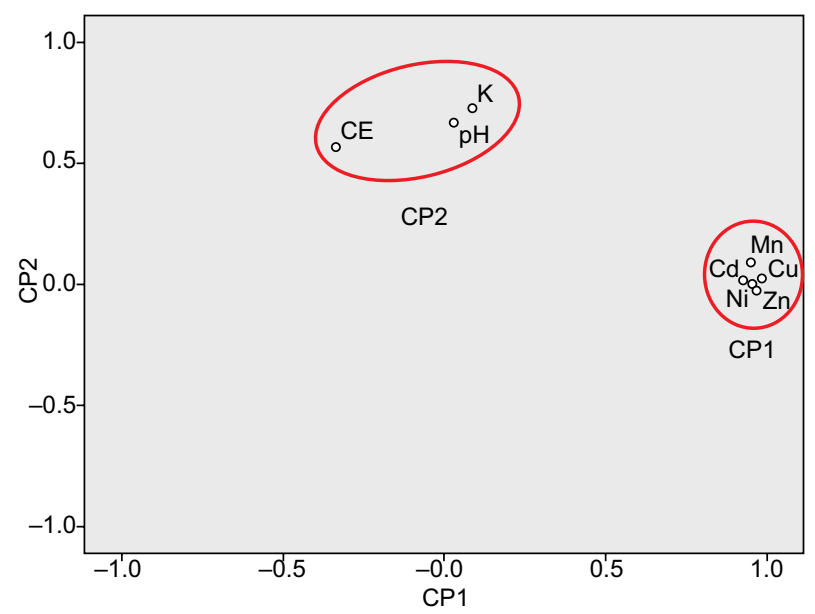

Fig. 6. Load graph for the PCA analysis, elements in each principal component are indicated in red circles.
González et al., 2017). One important aspect to address for this group, is the fact that they represent the rural area as well as the urban area. Therefore, it can be inferred that there is an influence of pollution across the urban gradient, affecting the surrounding rural areas which are connected by National Highway 85 -rural monitoring sites (Allende and Linares) are located at 1.66 and $0.8 \mathrm{~km}$ from the highway 85 , respectively-. The $\mathrm{CP} 2$ which explains $16.38 \%$ of the variance, is made up of $\mathrm{CE}, \mathrm{pH}$ and $\mathrm{K}$, and can be associated with the neutral $\mathrm{pH}$ behavior of the rain samples, since to some extent it was somewhat constant for all sites. The rest of the elements do not seem to have such a dominant effect on the distribution of the variance. To support the precise influence between the urban and rural areas in the transport of substances that can be deposited, a study on backward wind trajectories was carried out for both rural areas, Linares site (Fig.7a and 7b) and Allende site (Fig. 8a and 8b) during the winter and summer. No backward trajectories are shown for the MAM since Loya-Gonzalez et al. (2020) reported that the MAM is an emitter source rather than a receiver site.

Figure 7 a shows the backward wind trajectories (48 h) for all events collected during winter at the Linares site, at three different heights above ground level $(100,500$ and $1000 \mathrm{~m})$. Notice that most of the trajectories do not cross the MAM, only for 12 February 2019 to 100 AGL, the wind that came from the Pacific Ocean, entered through the Santa Catarina municipality, crossed the northern part of the MAM, then went down through the municipalities of Dr. González, Cadereyta Jiménez, General Terán, Montemorelos, finally reaching Linares. The dominant winds came from the north (USA), but they went through the eastern part of the state without crossing the MAM. Some winds also came from central Mexico or the Gulf of Mexico, entering mainly through the neighboring state of Tamaulipas and reaching Linares, which is located on the border between the state of Nuevo Leon and Tamaulipas.

The backward air mass trajectories (48 h) during summer are presented in Figure $7 \mathrm{~b}$, and represent all rainfall events collected at the Linares site during this season. Notice that most of the winds come from the southern part of the Gulf of Mexico. Only the trajectory on September 4, 2019 which corresponds to tropical storm Fernand, came from the northern 


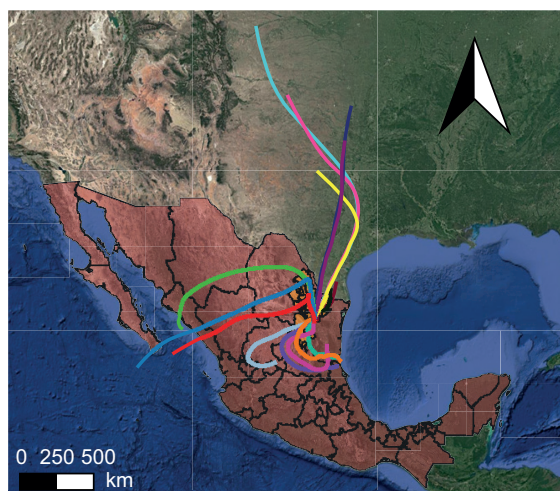

\section{SIMBOLOGY}

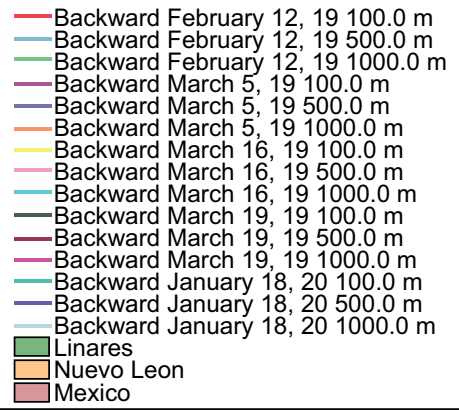

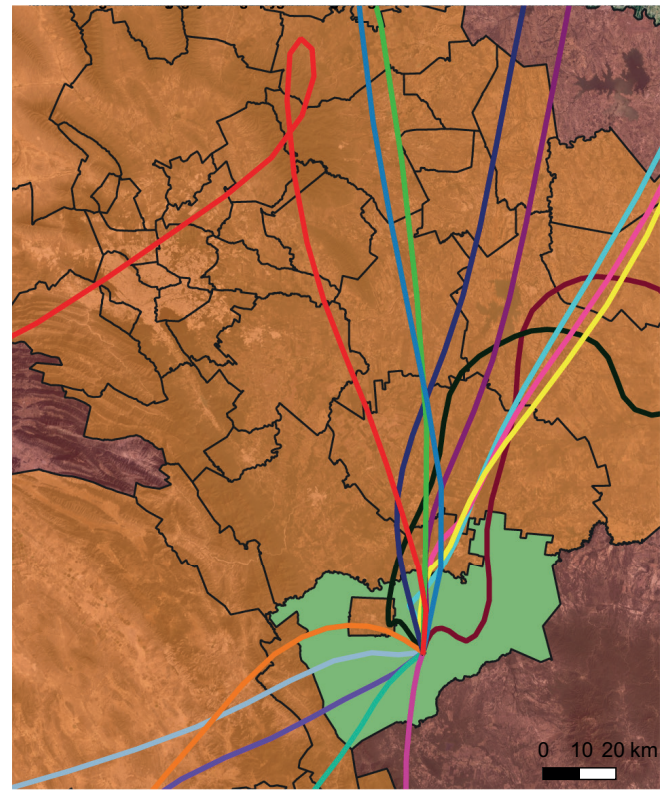

Fig. 7a. Air mass backward trajectories at 100, 500, and $1000 \mathrm{~m}$ AGL for Linares site, for all winter collected rainfall events.

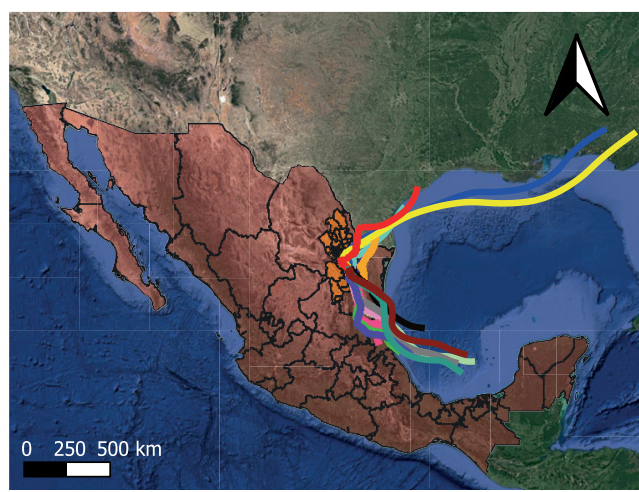

SIMBOLOGY

$$
\begin{aligned}
& \text { - Backward July 11, } 19100.0 \mathrm{~m} \\
& \text { - Backward Juy 11, } 99500.0 \mathrm{~m} \\
& \text { - Backward July 11, } 191000.0 \mathrm{~m} \\
& \text { - Backward August 26, } 19100.0 \mathrm{~m} \\
& \text { - Backward August 26, } 19500.0 \mathrm{~m} \\
& \text { - Backward August 26, } 191000.0 \mathrm{~m}
\end{aligned}
$$

Fig. 7b. Air mass backward trajectories at 100, 500, and $1000 \mathrm{~m}$ AGL for Linares site, for all summer collected rainfall events.

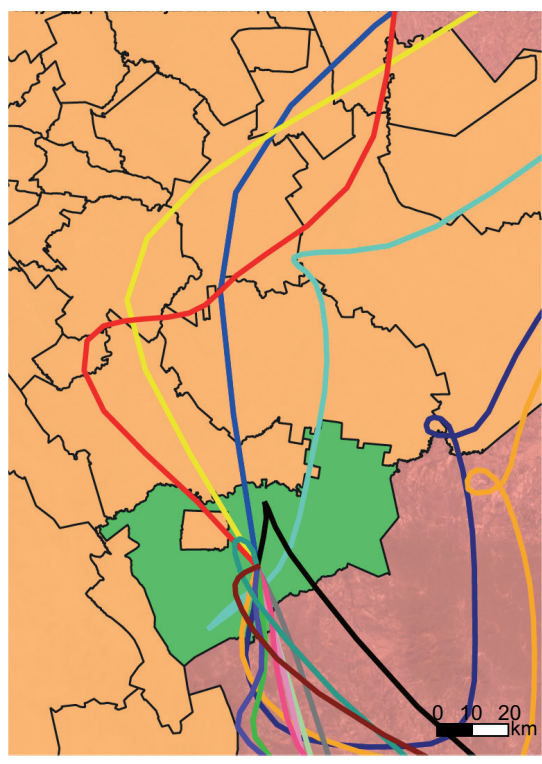



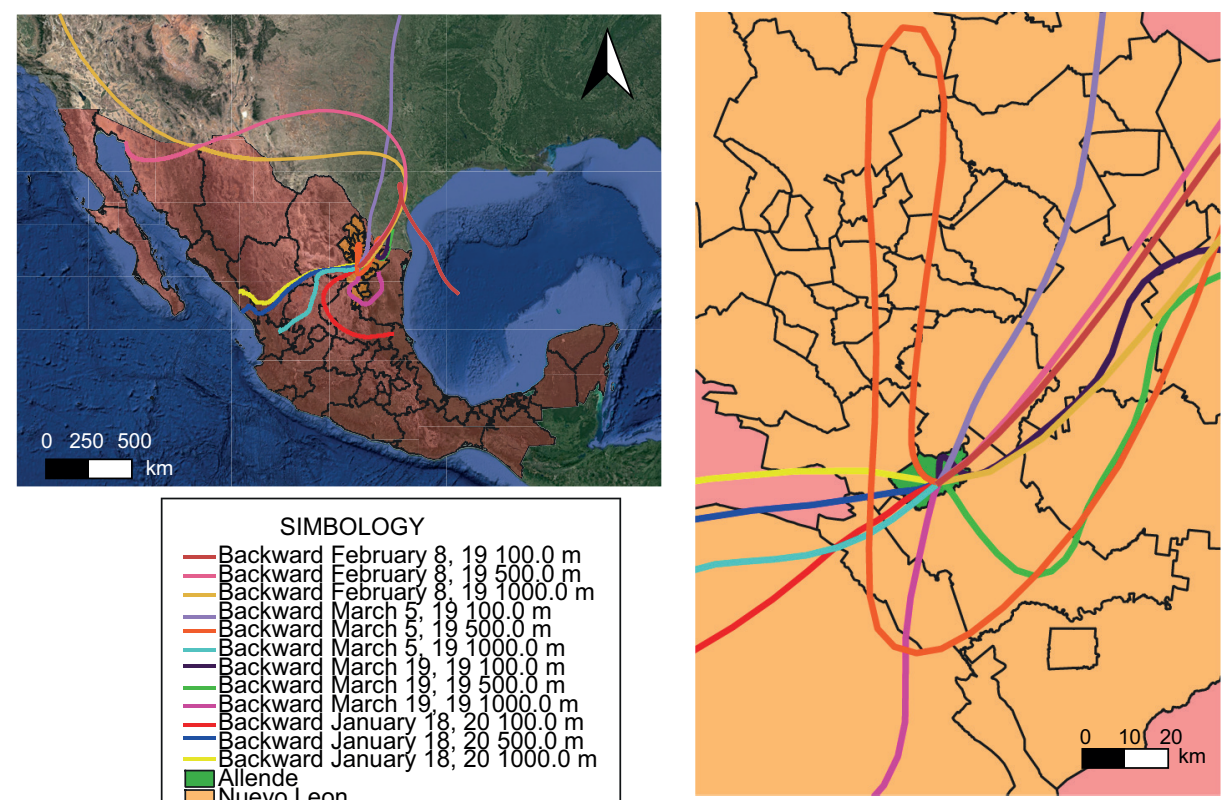

Fig. 8a. Air mass backward trajectories at 100, 500, and $1000 \mathrm{~m}$ AGL for Allende site, for all winter collected rainfall events.

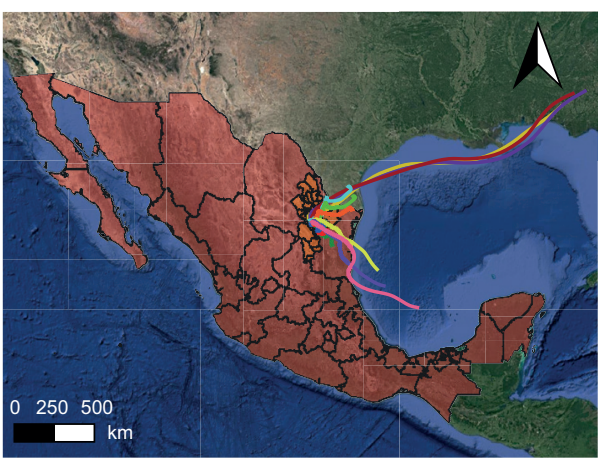

SIMBOLOGY
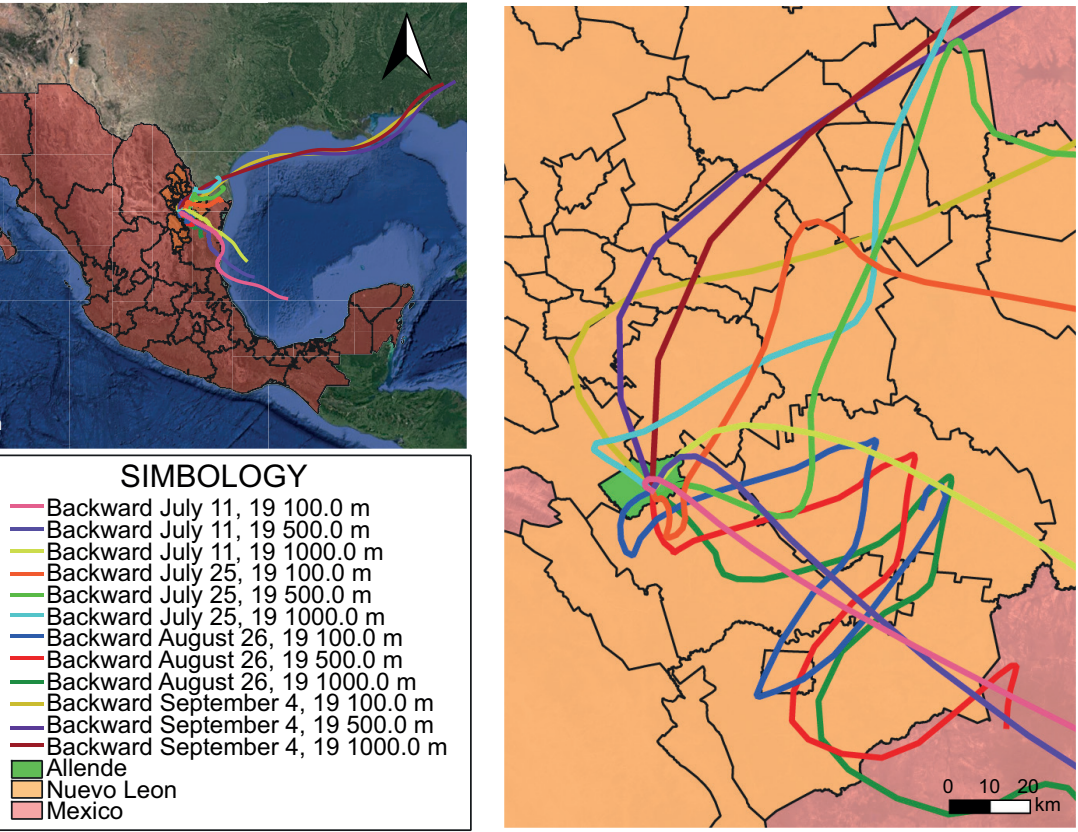

Fig. 8b. Air mass backward trajectories at 100, 500, and $1000 \mathrm{~m} \mathrm{AGL}$ for Allende site, for all summer collected rainfall events. 
part of the Gulf of Mexico, winds that had an origin near New Orleans and Atlanta. As can be seen, none of the trajectories crossed the MAM before reaching Linares; the only municipality of the MAM that is within the route of the summer trajectories is Cadereyta Jiménez where an oil refinery is located.

The backward air mass trajectories (48 h) at the Allende site for all the events collected during winter, are presented in Figure 8a, show that most of the winds come from the center of the country; only on 8 February 2019 the winds came from the north, crossing the northern of the State of Sonora and Chihuahua, until reaching Allende, without crossing the MAM. Only the trajectory of 5 March 2019 at an AGL of 500m, completely crossed the MAM from the northernmost part in Apodaca municipality and left through the municipality of Santiago, reaching Allende.

The backward air mass trajectories (48 h) at the Allende site for all the events collected during summer, are presented in Figure 8b, show that most of the winds come from the north (USA), especially during July and September. Also, these trajectories crossed the MAM before reaching Allende. On the other hand, during August the winds preferentially come from the Gulf of Mexico, entering Allende from the municipalities of Linares and Montemorelos. Therefore, the MAM can influence the presence and concentration of elements found at the Allende site, especially during summer. In contrast, little or almost no influence of the MAM at the Linares site can be confirmed for the seasons analyzed.

\subsection{Seasonal variation in element deposition and PCA analysis}

Seasonal deposition was analyzed to determine the influence of seasonality on deposition behavior for the chemical elements during the studied period, as seen in Figure 9. Deposition of $\mathrm{Zn}$ and Fe was higher during autumn, an increasing trend observed in the deposition of these elements from winter to autumn. Similarly, deposition of $\mathrm{Cd}, \mathrm{Cu}, \mathrm{Ni}$ and $\mathrm{Mn}$ increase from winter to autumn, reaching maximum values during autumn. In contrast, deposition of $\mathrm{K}$ is largest in winter and decreases in the rest of the seasons. Finally, $\mathrm{Ca}$ and $\mathrm{Mg}$ show a maximum in autumn and remain fairly constant throughout the other seasons.

In the case of deposition variability between seasons, the Krusakall-Wallis test shows significant differences for all elements $(p \leq 0.05)$ except for Fe $(p=0.444)$. Post hoc tests between seasons and differences between couples of seasons for each element are shown in Table VI. Results show that the spring-autumn, spring-summer, and winter-autumn pairs present the largest differences for all elements.

The PCA carried out to detect the grouping of variables in each season is shown in Table VII, where the factor loads for the components obtained according to the season of the year are displayed. Notice that 11 variables were analyzed, but the amount of data per season varied, with winter having 41 data points, autumn 171, summer 107 and spring 103. The rotated factors for the PCA components for each season were obtained using a varimax method with Kaiser normalization. The groups of elements that make up each component vary by season, reflecting a strong influence of the prevailing seasonal climate conditions on their deposition.

The elements that prevail independently of season and are always part of the CP1 of each seasonal analysis are $\mathrm{Cd}$ and $\mathrm{Cu}$, which reflects a constant source of emission throughout the year, primarily due to industrial emissions. During spring, CP1 grouped by $\mathrm{Zn}, \mathrm{Cd}, \mathrm{Cu}$, Ni and $\mathrm{Mn}$, as in the global CP1 (Fig. 6), showing an influence of industrial/ vehicular emissions sources. On the other hand, the $\mathrm{CP} 2$ grouped by $\mathrm{Fe}, \mathrm{Ca}, \mathrm{K}$ and $\mathrm{Mg}$, which can be related to natural emissions, except for Fe depositions in Universidad site, which is related to metallurgical emission sources. During autumn most of the elements were grouped within $\mathrm{CP} 1$ ( $\mathrm{Zn}, \mathrm{Cd}, \mathrm{Cu}, \mathrm{Ni}$ and $\mathrm{Ca}$ ), as in the global CP1 (Fig. 6) while in CP2 the $\mathrm{K}$ was the dominant variable, maybe due to strong winds during this season that can carry more dust to the atmosphere. Summer, shows two components and is clearly separated in $\mathrm{CP} 1$ elements like $\mathrm{Cd}, \mathrm{Cu}, \mathrm{Ni}$ and $\mathrm{Zn}$ (anthropogenic influence) from the $\mathrm{CP} 2 \mathrm{Mn}$, $\mathrm{Ca}, \mathrm{K}$ and $\mathrm{Mg}$ mostly from natural emissions (e.g. crustal dust). During winter, the elements that make up $\mathrm{CP} 1$ are $\mathrm{Cd}, \mathrm{Cu}$ and $\mathrm{Ca}$, which together could come from anthropogenic emissions due to industrial activity or exploitation of quarries; CP2 is made up of $\mathrm{Fe}, \mathrm{Mn}$ and $\mathrm{Mg}$ which are related to crustal material, except for $\mathrm{Fe}$ as already mentioned above. Winter shows a very peculiar behavior, because cold fronts influence the prevailing northerly winds -from the USA- as seen in backward trajectories at Linares and 


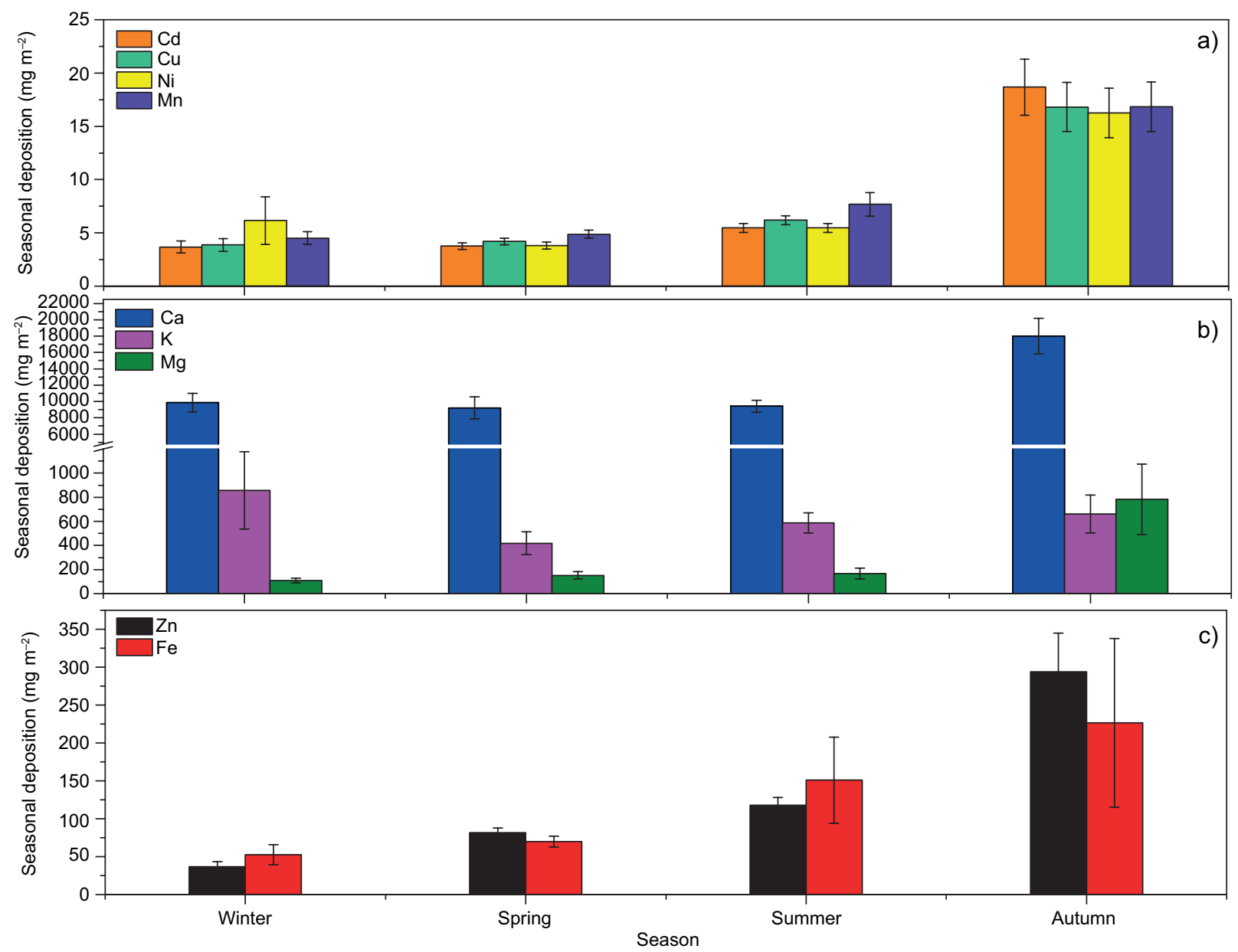

Fig. 9 Seasonal variation of deposition $\left(\mathrm{mg} \mathrm{m}^{-2}\right.$ ) of a) $\mathrm{Cd}, \mathrm{Cu}, \mathrm{Ni}$ and $\left.\mathrm{Mn}, \mathrm{b}\right) \mathrm{Ca}, \mathrm{K}$ and $\mathrm{Mg}$, and c) $\mathrm{Zn}$ and $\mathrm{Fe}$.

Allende sites (Figs. 7 and 8), affecting dispersion and pollutant concentrations. Winter is the most polluted season due to particulate matter (González-Santiago et al., 2011), and should be studied further to better understand the behavior of deposition during this season.

\subsection{Comparison between the deposition values ob- tained versus those reported in other studies}

Table VIII shows a comparison between the annual average deposition fluxes reported for each site in this study with others reported in the literature, where bulk deposition and some exclusively wet deposition are also used. The data reported by other studies allows us to identify how most of the values reported in this study were above the values of other studies in almost all cases. The $\mathrm{Zn}$ values for the
University site of the present study are higher than those reported in previous literature. In addition, for the rest of the sites analyzed, this research shows a relative high value compared to most of the studies that are reported in Table VIII.

$\mathrm{Fe}$ values for the University site are higher than those reported in the Daya Bay in China (Wu et al., 2018) and they are also higher than those reported for the CU-Metropolitan Area of the Valley of Mexico (García-Martínez, 2007), as well to the other values obtained for the rest of the monitoring sites of this investigation. Furthermore, the $\mathrm{Cd}$ reported here exceeds all values of other studies given in Table VIII, and the Ni value is only exceeded by the location reported from Yangtze River Delta in China (Ma et al., 2019). In the case of Mn deposition, Luna-Robles et al. (2019) in Linares, Mexico, and 
Table VI. Results of Post hoc for Kruskal-Wallis test with Bonferroni correction for the elements that show significant differences between seasons.

\begin{tabular}{lcrc}
\hline Season 1- Season 2 & Element & Test statistic & Adj. Sig. \\
\hline Spring-Summer & $\mathrm{Zn}$ & -97.545 & 0.000 \\
Winter-Summer & $\mathrm{Zn}$ & -135.703 & 0.000 \\
Spring-Autumn & $\mathrm{Zn}$ & 48.563 & 0.008 \\
Autumn-Summer & $\mathrm{Zn}$ & 86.721 & 0.000 \\
\hline Winter-Autumn & $\mathrm{Cd}$ & -60.109 & 0.046 \\
Spring-Summer & $\mathrm{Cd}$ & -55.524 & 0.001 \\
Spring-Autumn & $\mathrm{Cd}$ & -57.665 & 0.001 \\
\hline Winter-Autumn & $\mathrm{Cu}$ & -63.969 & 0.027 \\
Winter-Summer & $\mathrm{Cu}$ & -77.218 & 0.003 \\
Spring-Autumn & $\mathrm{Cu}$ & -52.073 & 0.004 \\
Spring-Summer & $\mathrm{Cu}$ & -65.323 & 0.000 \\
\hline Winter-Autumn & $\mathrm{Ni}$ & -60.178 & 0.045 \\
Winter-Summer & $\mathrm{Ni}$ & -64.792 & 0.023 \\
Spring-Autumn & $\mathrm{Ni}$ & -47.555 & 0.011 \\
Spring-Summer & $\mathrm{Ni}$ & -52.169 & 0.003 \\
\hline Spring-Summer & $\mathrm{Mn}$ & -52.114 & 0.003 \\
\hline Spring-Summer & $\mathrm{Ca}$ & -46.055 & 0.013 \\
\hline Spring-Autumn & $\mathrm{K}$ & -57.864 & 0.001 \\
Spring-Winter & $\mathrm{K}$ & 75.802 & 0.002 \\
Spring-Summer & $\mathrm{K}$ & -88.728 & 0.000 \\
\hline Spring-Summer & $\mathrm{Mg}$ & -51.518 & 0.004 \\
Spring-Autumn & $\mathrm{Mg}$ & -55.300 & 0.001 \\
\hline As & & &
\end{tabular}

Asymptotic meanings are shown (two-tailed tests). The significance level is 0.05
Wu et al. (2018) in Daya Bay, China, showed greater depositions values than those obtained in all sites in this study. Calcium exceeds all values reported in other studies, but in the case of Linares site the $\mathrm{Ca}$ deposited is lower than the reported for the same site during 2016-2017 (Luna-Robles et al., 2019). K and $\mathrm{Mg}$ values reported by the previous study in Linares site are higher than in this study, only $\mathrm{Mg}$ values in Pueblo Serena site are greater than those previously reported (Luna-Robles et al., 2019).

\section{Conclusions}

A total of 422 rainwater samples were collected in 32 rain events. An average $\mathrm{pH}$ of $7.15 \pm 0.02$ was found, indicating the presence of neutralizing substances in rainwater, influenced by predominantly calcareous soils in the study region. The average EC was 153.96 $\pm 6.83 \mu \mathrm{S} / \mathrm{cm}$ and exhibits high variability throughout the year.

Rainfall events show significant differences for all the deposited elements analyzed and between monitoring sites $(\mathrm{p} \leq 0.05)$. Likewise, they show significant diferences between urban and rural sites for $\mathrm{Cd}, \mathrm{Fe}, \mathrm{Ni}$ and $\mathrm{Ca}(\mathrm{p} \leq 0.05)$, but not for $\mathrm{Zn}(\mathrm{p}=0.654)$, $\mathrm{Cu}(\mathrm{p}=0.296), \mathrm{Mn}(\mathrm{p}=0.579), \mathrm{K}(\mathrm{p}=0.537)$ and $\mathrm{Mg}$ $(\mathrm{p}=0.094)$. Post hoc test showed that tropical storm Fernand marked the difference for all the elements with respect to other rainfall events. Also, a remarkable difference was found between the Linares

Table VII. PCA factor loadings for each season (PCA loadings $>0.7$ are shown in bold).

\begin{tabular}{lcccccccc}
\hline \multirow{2}{*}{ Variables } & \multicolumn{2}{c}{ Winter } & \multicolumn{2}{c}{ Spring } & \multicolumn{2}{c}{ Summer } & \multicolumn{2}{c}{ Autumn } \\
\cline { 2 - 9 } & CP1 & CP2 & CP1 & CP2 & CP1 & CP2 & CP1 & CP2 \\
\hline Zn & & & $\mathbf{0 . 9 1 6}$ & & $\mathbf{0 . 8 2 1}$ & & $\mathbf{0 . 9 7 5}$ & \\
$\mathrm{Cd}$ & $\mathbf{0 . 9 5 9}$ & & $\mathbf{0 . 9 8 6}$ & & $\mathbf{0 . 9 8 8}$ & & $\mathbf{0 . 8 9 4}$ & \\
$\mathrm{Fe}$ & & $\mathbf{0 . 9 3 5}$ & & $\mathbf{0 . 6 7}$ & & & & \\
$\mathrm{Cu}$ & $\mathbf{0 . 9 0 5}$ & & $\mathbf{0 . 9 4 8}$ & & $\mathbf{0 . 9 4 5}$ & & $\mathbf{0 . 9 7 7}$ & \\
$\mathrm{Ni}$ & & & $\mathbf{0 . 9 8 4}$ & & $\mathbf{0 . 9 8 8}$ & & $\mathbf{0 . 9 7 8}$ & \\
$\mathrm{Mn}$ & & $\mathbf{0 . 7 5 3}$ & $\mathbf{0 . 8 2 5}$ & & & $\mathbf{0 . 8 8 2}$ & & \\
$\mathrm{Ca}$ & $\mathbf{0 . 8 4 2}$ & & & $\mathbf{0 . 8 1 3}$ & & $\mathbf{0 . 7 2 1}$ & $\mathbf{0 . 9 3 7}$ & \\
$\mathrm{K}$ & & & & $\mathbf{0 . 9 3 9}$ & & $\mathbf{0 . 9 6 4}$ & & $\mathbf{0 . 8 2 2}$ \\
$\mathrm{Mg}$ & & $\mathbf{0 . 7 7 5}$ & & $\mathbf{0 . 9 0 9}$ & & $\mathbf{0 . 9 6 8}$ & & 0.493 \\
Eigenvalue & 4.25 & 1.84 & 4.75 & 2.94 & 5.33 & 2.43 & 5.96 & 1.04 \\
\% of variance & 47.27 & 20.38 & 47.51 & 29.47 & 59.28 & 27.05 & 66.27 & 11.58 \\
\% accumulative & & $\mathbf{6 7 . 6 5}$ & & $\mathbf{7 6 . 9 8}$ & & $\mathbf{8 6 . 3 3}$ & & $\mathbf{7 7 . 8 5}$ \\
\hline
\end{tabular}

Note: Components extracted with Varimax rotation method with Kaiser normalization. 


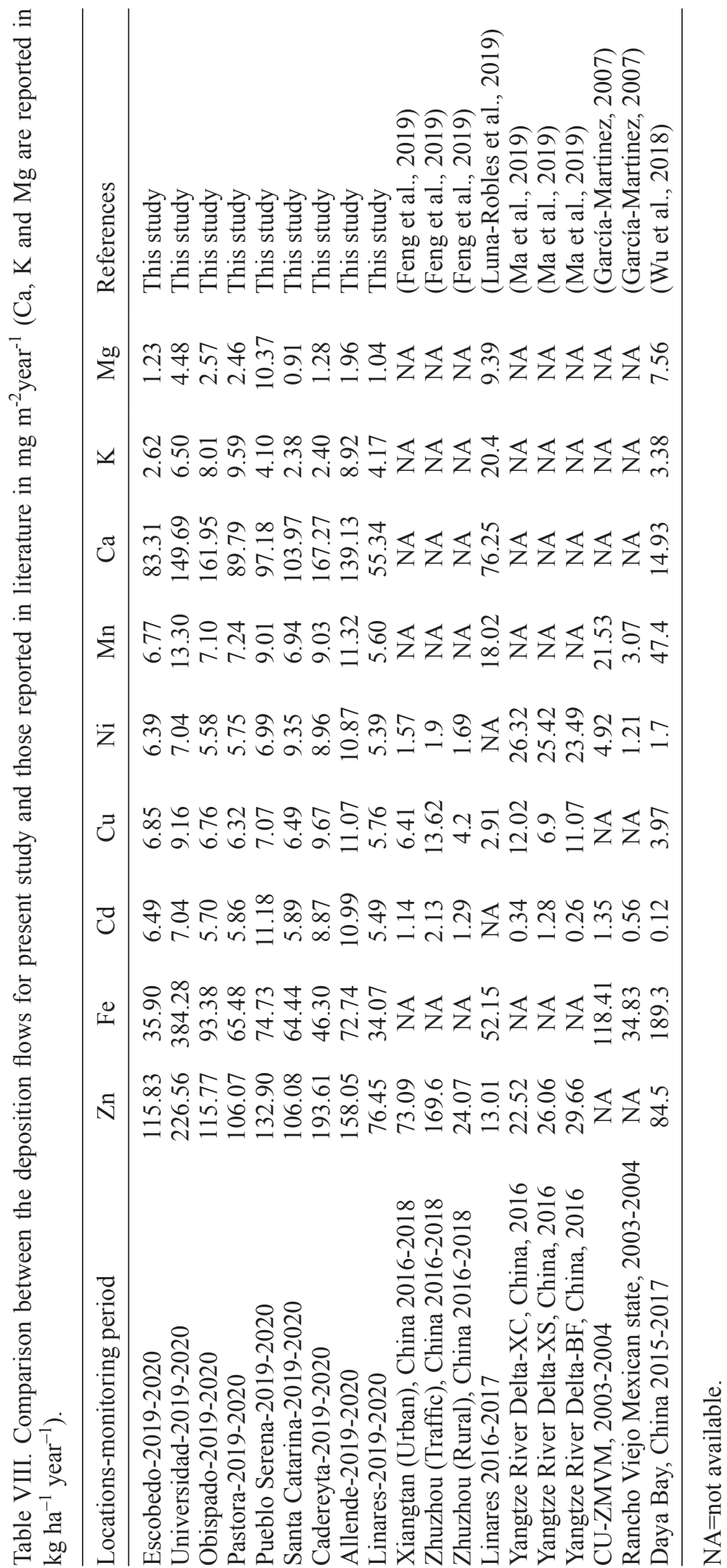


site with respect to Universidad site, for $\mathrm{Fe}$ and $\mathrm{Ca}$ deposition.

The annual accumulated deposition follows a descending order $\mathrm{Ca}>\mathrm{K}>\mathrm{Mg}>\mathrm{Fe}>\mathrm{Zn}>\mathrm{Mn}>\mathrm{Cu}>\mathrm{Cd}>$ $\mathrm{Ni}$ and does not show significant differences in the annual deposition amounts between urban and rural areas $(p=0.317)$, with the exception of $\mathrm{Ca}(\mathrm{p}=0.017)$. High correlations can be observed between metals, especially $\mathrm{Cd}-\mathrm{Cu}, \mathrm{Cd}-\mathrm{Ni}, \mathrm{Cd}-\mathrm{Mn}, \mathrm{Cu}-\mathrm{Ni}, \mathrm{Cu}-\mathrm{Mn}$ and Ni-Mn, primarily due to the influence of industrial (metallurgical) and vehicular emissions. PCA shows that $\mathrm{Cu}, \mathrm{Zn}, \mathrm{Ni}, \mathrm{Mn}$, and $\mathrm{Cd}$, represent an important pathway in the deposition phenomena, and they reflect that both the urban and rural areas studied maintain the same behavior for this group of elements, which denotes that the rural areas could be connected to the air basin of the MAM. It was not expected that deposition patterns would be similar between urban and rural areas with such different types and levels of activity, nor that they would present similarities regarding the deposition of toxic metals such as $\mathrm{Cd}$.

Enrichment Factors calculated for all elements at each site, using $\mathrm{Fe}$ and $\mathrm{Ca}$ as conservative elements, showed that $\mathrm{Zn}$ and $\mathrm{Cd}$ exhibit a high enrichment, while $\mathrm{Cu}$ and $\mathrm{Ni}$ have a moderate enrichment in all sites. On the other hand, only $\mathrm{K}, \mathrm{Mg}$ and $\mathrm{Mn}$ were not enriched, except for EF values for Mn in Universidad and Santa Catarina, where enrichment was moderate.

Seasonal deposition showed that $\mathrm{Fe}, \mathrm{Zn}, \mathrm{Cd}, \mathrm{Cu}$, $\mathrm{Ni}, \mathrm{Mn}, \mathrm{Ca}$, and $\mathrm{Mg}$ were higher during autumn; in contrast, K was higher during winter. Seasonal PCA shows that during spring and summer deposition separates more clearly into metals and elements of crustal origin, like the global PCA. On the other hand, during winter and autumn, the patterns change with respect to those reported by the global PCA and the rest of the seasons, maintaining a particular pattern for autumn and for winter.

Backward trajectories of rain events collected during winter and summer, at Linares and Allende rural sites, showed that only for Allende site a possible carry-over of pollutants is observed during summer, since winds preferably come from the northern part of the MAM during that season. However, it is recommended to carry out further analyzes on winds throughout the year, to more clearly detect possible sources of emissions that could affect Allende and Linares sites.
It is important to continue with the implementation of studies that define the deposition along the urban gradient of the MAM, separating wet and dry depositions, due to the high urbanization and the increasing problems of air pollution. Furthermore, it is necessary to evaluate the deposition of toxic metals to establish government strategies aimed at improving air quality and ensuring an environment free of toxic substances for human and ecosystem health.

\section{Acknowledgments}

Darithsa Loya-González thanks the Consejo Nacional de Ciencia y Tecnología (CONACYT) for the scholarship provided (No. 660428). The authors are grateful for the support given by the Sistema Integral de Monitoreo Ambiental (SIMA) for the use of environmental monitoring stations, as well as Arch. Jorge Alfonso Llanas Mendoza for the availability for the installation of collectors within high school No. 13 of UANL.

\section{References}

Alcalá Escamilla B, López López A. 2017. Zonas con potencial agroturístico en la región citrícola de Nuevo León, México: una análisis a partir del álgebra de mapas. Cuadernos de turismo 39: 17-40. https://doi. org/10.6018/turismo.39.290371

Alves DD, Backes E, Rocha-Uriartt L, Plangg Riegel R, Müller de Quevedo D, Schmitt Jairo L, Marques da Costa G, Migliavacca Osório DM. 2018. Chemical composition of rainwater in the Sinos River basin, Southern Brazil: a source apportionment stidy. Environmental Science and Pollution Research 25: 2415024161. https://doi.org/10.1007/s11356-018-2505-1

Anil I, Alagha O, Karaca F. 2017. Effects of transport patterns on chemical composition of sequential rain samples: trajectory clustering and principal component analysis approach. Air Quality, Atmosphere and Health 10: 1193-1206. https://doi.org/10.1007/ s11869-017-0504-x

Cable E, Deng Y. 2018. Trace elements in atmospheric wet precipitation in Detroit Metropolitan Area: levels and possible sources. Chemosphere 210: 1091-1098. https://doi.org/10.1016/j.chemosphere.2018.07.103

Cerón RM, Ceron JG, Aguilar CA, Montalvo C, López U, Carballo CG, Benítez JA, Carrillo JR. 2018. Variations 
in criterio pollutants and deposition fluxes of trace elements in Metropolitan Area of Monterrey, Mexico. Latest Trends in Energy, Environment and Development 321-328. Proceedings of the 7th International Conference on Environmental and Geological Science and Engineering (EG ' 14 ), Organized by WSEAS and presented in Salerno, Italia del 3-5 June 2014. ISSN: 2227-4359, ISBN: 978-960-474-375-9.

Charlson RJ, Rodhe H. 1982. Factors controlling the acidity of natural rainwater. Nature 295: 682-685. https:// doi.org/https://doi.org/10.1038/295683a0

Chen L, Zhou S, Wu S, Wang C, He D. 2019. Concentration fluxes, risks and sources of heavy metals in atmospheric deposition in the Lihe River Watershed, Taihu Region, eastern China. Environmental Pollution 255, part 2, 113301. https://doi.org/10.1016/j. envpol.2019.113301

Chia-Te Chien, Brant A, Dimova NT, Yang J, Reuter J, Schladow G, Paytan A. 2019. Evaluations of atmospheric dry deposition as a source if nutrients and trace metals to Lake Tahoe. Chemical Geology 511: 178-189. https://doi.org/10.1016/j.chemgeo.2019.02.005

CONAGUA. 2020. Información estadística climatológica. Available at https://smn.conagua.gob.mx/es/climatologia/informacion-climatologica/informacion-estadistica-climatologica (accessed 2020 December 18).

Csavina J, Field J, Taylor MP, Gao S, Landázuri A, Betterton EA, Sáez AE. 2012. A review on the importance of metals and metalloids in atmospheric dust and aerosol from mining operations. Science of the Total Environment 433: 58-73. https://doi.org/10.1016/j. scitotenv.2012.06.013

Ediagbonya TF. 2016. Enrichment factor of atmospheric trace metal using Zirconium, Titanium, Iron and Copper as reference element. Nigerian Journal of Technology 35: 785-795. https://doi.org/10.4314/njt.v35i4.13

Facchini Cerqueira MR, Fonseca Pinto M, Nunes Derossi I, Tinoco Esteves W, Rachid Santos MD, Costa Matos MA, Lowinsohn D, Camargo Magos R. 2014. Chemical characteristics of rainwater at a Southeastern site of Brazil. Atmospheric Pollution Research 5: 253-261. https://doi.org/10.5094/APR.2014.031

García-Martínez, R. 2007. Determinación de metales pesados en la precipitación pluvial de una zona urbana (Cd. México) y una zona rural (Rancho Viejo, Edo. México). Doctoral thesis, Universidad Autónoma de México.
Gobierno del Estado de Nuevo León. 2016. Pro Aire Nuevo León 2016-2025. Available at https://www.gob.mx/ $\mathrm{cms} /$ uploads/attachment/file/250974/ProAire_Nuevo_Leon.pdf (accessed 2020 June 26).

González-Santiago O, Badillo-Castañeda CT, Kahl J, Ramírez-Lara E, Balderas-Rentería I. 2011. Temporal analysis of PM10 in Metropolitan Monterrey, Mexico. Journal of the Air and Waste Management Association 61: 573-579. https://doi.org/10.3155/10473289.61.5.573

González LT, Longoria Rodríguez FE, Sánchez Domínguez M, Leyva-Porras C, Silva-Vidaurri LG, Acuna-Askar K, Kharisov BI, Villarreal Chiu JF, Alfaro Barbosa JM. 2016. Chemical and morphological characterization of TSP and Pm2.5 by SEM-EDS, XPS and XRD collected in the Metropolitan Area of Monterrey, Mexico. Atmospheric Environment 143: 249-260. https://doi. org/10.1016/j.atmosenv.2016.08.053

González LT, Longoria Rodríguez FE, Sánchez Domínguez M, Cavazos A, Leyva Porras C, Silva-Vidaurri LG, Acuna-Askar K, Kharisov BI, Villarreal Chiu JF, Alfaro Barbosa JM. 2017. Determination of trace metals in TPS and PM2.5 materials collected in the Metropolitan Area of Monterrey, Mexico: a characterization study by XPS, ICP-AES and SEM-EDS. Atmospheric Research 196: 8-22. https://doi.org/10.1016/j.atmosres.2017.05.009

Granat L, Suksomsankh K, Simachaya S, Tabucanont M, Rodhe H. 1996. Regional background acidity and chemical composition of precipitation in Tailand. Atmospheric Environment 30: 1589-1596. https://doi. org/10.1016/1352-2310(95)00455-6

INAFED. 2010. Enciclopedia de los municipios y delegaciones de México. Available at http://www.inafed. gob.mx/work/enciclopedia/EMM15mexico/index.html (accessed 2020 December 18).

Izquierdo R, Avila A. 2013. Comparison of collection methods to determine atmospheric deposition in a rural mediterranean site (NE Spain). Journal of Atmospheric Chemistry 69: 351-368. https://doi.org/10.1007/ s10874-012-9246-1

Khaniabadi YO, Daryanoosh SM, Amrane A, Polosa R, Hopke PK, Goudarzi G, Mohammadi MJ, Sicard P, Armin H. 2017. Impact of middle eastern dust storms on human health. Atmospheric Pollution Research 8: 606-613. https://doi.org/10.1016/j.apr.2016.11.005

Loya-González D, López-Serna D, Alfaro-Barbosa JM, López-Reyes A, González-Rodríguez H, Cantú-Silva I. 2020. Chemical composition of bulk precipitation 
and its toxicity potential index in the Metropolitan Area of Monterrey, Northeastern Mexico. Environments 7: 106. https://doi.org/doi:10.3390/environments7120106 Luna-Robles EO, Cantú-Silva I, González-Rodríguez H, Marmolejo-Monsiváis JG, Yáñez-Díaz MI, Béjar-Pulido SJ. 2019. Nutrient imput via gross rainfall, troughfall and steamflow in scrubland species in Northeastern Mexico. Revista Chapingo, Serie Ciencias Forestales y del Ambiente 25: 235-251. https://doi.org/10.5154/r. rchscfa.2018.12.096

Ma Y, Tang Y, Xu H, Zhang X, Liu H, Wang S. 2019. Bulk/ wet deposition of trace metals to rural, industrial and urban areas un the Yangtze River Delta, China. Ecotoxicology and Environmental Safety 169: 185-191. https://doi.org/10.1016/j.ecoenv.2018.11.002

Mason B, Moore C. 1982. Principles of Geochemsitry. New York: John Wiley and Sons, Inc Editions.

McKenzie ER, Money JE, Green PG, Young TM. 2009. Metals associated with stormwater-relevant brake and tire samples. Science of Total Environment 407: 5855-5860. https://doi.org/10.1016/j.scitotenv.2009.07.018

Moreda-Piñeiro J, Alonso-rodríguez E, Turnes-Carou I, Moscoso-Pérez C, Blanco-Heras G, Gómez-Tellado L, López-Mahía P, Muniategui-Lorenzo S, Prada-Rodríguez D. 2017. Inorganic ions and trace metals bulk deposition at an Atlantic Coastal European Region. Journal of Atmospheric Chemistry 74: 1-21. https:// doi.org/10.1007/s10874-016-9338-4

Naifar I, Pereira F, Zmemla R, Bouaziz M, Elleuch B, Garcia D. 2018. Spatial distribution and contamination assessment of heavy metals in marine sediments of the Southern Coast of Sfax, gabes Gulf, Tunisia. Marine Pollution Bulletin 131: 53-62. https://doi. org/10.1016/j.marpolbul.2018.03.048

Nowak DJ, Hirabayashi S, Doyle M, McGovern M, Pasher J. 2018. Air pollution removal by urban forests in Canada and its effect on air quality and human health. Urban Forestry and Urban Greening 29: 40-48. https:// doi.org/10.1016/j.ufug.2017.10.019

Pantoja-Zavala GM, Flores-Vichi F. 2018. Citrus sector of Nuevo Leon: characterization of the agri-food system as a platformn for integration of the producer with agro-industry. Region y Sociedad 30(71). https://doi. org/10.22198/rys.2018.71.a385

Quiterio SL, Sousa da Silva CR, Arbilla G, Escaleira V. 2004. Metals in airborne particulate matter in the industrial district of Santa Cruz, Rio de Janeiro, in an annual period. Atmospheric Environment 38: 321-331. https://doi.org/10.1016/j.atmosenv.2003.09.017

Ramírez-Lara E, Cerón-Bretón RM, Cerón-Bretón JG, López-Chuken U, Kahl J. 2016. Study of trace ions in wet deposition o fan industrial site in Monterrey's Metropolitan Area, Mexico. Open Journal of Ecology 6: 1-12. https://doi.org/. http://dx.doi.org/10.4236/ oje.2016.61001

SEMARNAT. 2016. Poblacion, superficie y densidad urbana en zonas metropolitanas. Available https:// apps 1.semarnat.gob.mx:8443/dgeia/compendio_2016/ archivos/04_procesourbanizacion/D1_SISCDS01_02. pdf (accessed 2020 June 26).

Sharma A, Kulshrestha UC. 2020. Wet deposition and long-range transport of major ions related to snow at Northwertern Himalays (India). Aerosol and Air Quality Research 20: 1249-1265. https://doi.org/10.4209/ aaqr.2019.06.0279

Singh RL. 2017. Principles and applications of environmental biotechnology for a sustainable future. Singapore: Springer.

Siudek P, Frankowski M. 2017. Atmospheric depositions of trace elements at urban and forest sites in Central Poland- insight into seasonal variability and sources. Atmospheric Research 198: 123-131. https://doi. org/10.1016/j.atmosres.2017.07.033

Szép R, Mateescu E, Nechifor AC, Keresztesi A. 2017. Chemical characteristics and source analysis on ionic composition of rainwater collected in the Carpathians 'Cold Pole' ciuc basin, Eastern Carpathians, Romania. Environmental and Pollution Research 24: 27288272302. https://doi.org/10.1007/s11356-017-0318-2

Valdez Cerda E, Hinojosa Reyes L, Alfaro Barbosa JM, Elizondo Martínez P, Acuña-Askar K. 2011. Contamination and chemical fractionation of heavy metals in street dust from Metropolitan Area of Monterrey, Mexico. Environmental Techonology 32: 1163-1172. https://doi.org/10.1080/09593330.2010.529466

Wright LP, Zhang L, Cheng I, Aherne J, Wentworth GR. 2018. Impacts and effects indicators of atmospheric deposition of major pollutants to various ecosystems- A review. Aerosol and Air Quality Research 18: 19531992. https://doi.org/10.4209/aaqr.2018.03.0107

Wu Y, Zhang J, Ni Z, Liu S, Jiang Z, Huang X. 2018. Atmospheric deposition of trace elements to Daya Bay, South China Sea: fluxes and sources. Marine Pollution Bulletin 127: 672-683. https://doi.org/10.1016/j.marpolbul.2017.12.046 
Yáñez-Díaz MI, Cantú-Silva I, González-Rodríguez H, Uvalle-Sauceda JI. 2014. Redistribution of precipitation in three native brush species and a eucalyptus plantings in Northeastern Mexico. Tecnologia y Ciencias del Agua 5: 71-84.

Zheng Z, Xu G, Li Q, Chen C, Li J. 2019. Effect of precipitation on reducing atmospheric pollutant over Beijing. Atmospheric Pollution Research 10: 1443-1453. https://doi.org/10.1016/j.apr.2019.04.001
Zhou S, Yuan Q, Li W, Lu Y, Zhang Y, Wang W. 2014. Trace metals in atmospheric fine particles in one industrial urban city: spatial variations, sources, and health implications. Journal of Environmental Sciences 26: 205-213. https://doi.org/10.1016/S10010742(13)60399-X 